\title{
HUNTER-GATHERER EARTH OVENS IN THE ARCHAEOLOGICAL RECORD: FUNDAMENTAL CONCEPTS
}

\author{
Stephen L. Black and Alston V. Thoms
}

\begin{abstract}
Remains of earth ovens with rock heating elements of various sizes and configurations are common at hunter-gatherer sites around the world. They span the last 30,000 years in the Old World and some 10,000 years in the New World. Although various foods were baked in these ovens, plants predominate. Earth ovens are ethnographically well documented as family-size and bulk cooking facilities, but related technology and its archaeological signatures remain poorly understood and understudied. These ubiquitous features are often mischaracterized as generic cooking facilities termed hearths. It is proposed that, in fact, most rock "hearths" are heating elements of earth ovens. Reliable identification and interpretation of earth ovens requires documentation of heating elements, pit structure, rock linings, and various remnants thereof. Fundamental technological concepts for investigating their archaeological signatures include thermodynamics, construction designs, and life cycles in systemic context, as informed by ethnographic, archaeological, and experimental data. Earth oven technology explains well the primary purpose of labor-intensive thermal storage for long-term cooking and conserving fuel. Information from the extensive archaeological record of earth ovens on the Edwards Plateau of south-central North America illustrates these points.
\end{abstract}

Los restos de hornos de tierra con elementos de calefacción de roca de varios tamaños y configuraciones son comunes en los sitios de cazadores-recolectores de todo el mundo. Ellos abarcan los últimos 30,000 años en el Viejo Mundo y cerca de 10,000 años en el Nuevo Mundo. Aunque varios alimentos se cuecen en estos hornos, predominan las plantas. Hornos de la tierra están bien documentados etnográficamente como de tamaño familiar y las instalaciones de cocina a granel, pero la tecnología conexa y sus firmas arqueológicos siguen siendo poco conocidos y poco estudiado. Estas características ubicuas son a menudo mal identificados como instalaciones de cocina genéricos denominados hogares. Se propone que, de hecho, la mayoría de los "hogares de roca" son elementos de calentamiento de hornos de tierra. La identificación fiable e interpretación de los hornos de tierra requiere documentación de los elementos de calefacción, la estructura de pozo, revestimientos de piedra, y varios restos de los mismos. Conceptos tecnológicos fundamentales para la investigación de sus firmas arqueológicos incluyen la termodinámica, diseños de construcción, y los ciclos de vida en el contexto sistémico, según se informa en los datos etnográficos, arqueológicos y experimental. Tecnología de horno de la tierra explica bien el objetivo principal de almacenamiento térmico de mano de obra para cocinar a largo plazo y la conservación de combustible. Información del extenso registro arqueológico de hornos de tierra en la Edwards Plateau en el sur-centro de América del Norte ilustra estos puntos.

$\mathrm{C}$ ooking features archaeologists often call "hearths" are the most common and potentially informative features found at hunter-gatherer sites around the world, yet many are not hearths at all, and conceptualizing them as such undermines their research potential. Mischaracterized or not, hunter-gatherer cooking features help identify sites, living surfaces, and activity areas; they are used to evaluate depositional environment and integrity; they are prime sources of datable carbon and identifiable floral materials; and they provide important measures of landscape use that bear directly on basic subsistence practices, mobility, resource scheduling, feasting, gender, and population issues. ${ }^{1}$

The term hearth is appropriately applied to relatively small surface features used for shortterm dry-heat cooking, warmth, and light that are ethnographically known from foraging societies worldwide. Although hearths would have been common in the systemic contexts that resulted in hunter-gatherer sites, most are invisible in many

Stephen L. Black - Texas State University, San Marcos, TX 78666 (sblack@txstate.edu)

Alston V. Thoms - Texas A\&M University, College Station, TX 77843-4352 (a-thoms@tamu.edu) 


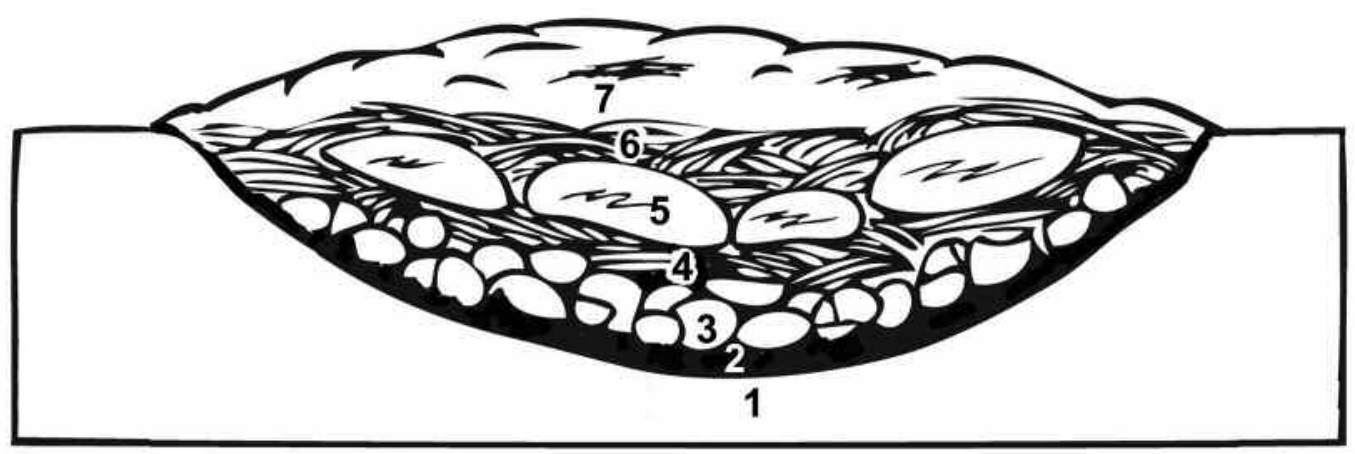

Figure 1. Idealized earth oven section diagram showing seven layers: (1) prepared surface (oven pit), (2) fire (reduced to ashes and glowing coals by the time the oven is sealed), (3) layer of red-hot rocks (heating element), (4) lower layer of green plant material (packing), (5) food layer, (6) upper layer of packing, and (7) earthen cap (adapted from Thoms 1989:268, Figure 21).

archaeological contexts simply because most traces of their existence are ephemeral and do not survive the passage of time.

In stark contrast, the telltale remains of the typically larger, more specialized, and longer-term cooking features appropriately known as "earth ovens" are readily apparent and commonly encountered by hunter-gatherer archaeologists, although often termed hearths. An earth oven is a layered cooking arrangement of fire, heated rocks (usually), food, green-plant packing materials, and sediment designed to bake food in moist heat at an even, relatively low temperature for periods of time ranging from a few hours to several days (Figure 1). Most of the layers, especially the namesake cap of earth, are rarely discernible in the archaeological record, but not so for the once-hot rocks.

Globally for tens of thousands of years humans have baked foods in earth ovens using rocks to store and slowly release heat. In North America, evidence for this technology dates back to some 10,000 years ago (Leach et al. 2006; Thoms 2009). Thereafter, the Holocene archaeological record across much of the continent is littered, sometimes quite literally, with earth oven debris, most notably spent cooking stones typically termed burned or fire-cracked rocks (FCR). ${ }^{2} \mathrm{Al}-$ though earth ovens are most characteristic of foragers, they are found among agricultural societies as well (Castetter et al. 1938; Fish and Fish 1992; Miller et al. 2011; Whalen and Minnis 2009).

Earth ovens are oft-reused cooking facilities with characteristic archaeological signatures, the most telling of which is often a circular arrangement .5-3 $\mathrm{m}$ in diameter of closely spaced, fire- cracked rocks that served as a heating element (i.e., thermal storage layer). Such relatively intact patterns are often found in association with scattered or amassed accumulations of highly fractured, discarded cooking stones. FCR alone give most earth oven facilities extraordinary archaeological visibility. Even when the primary structure is disrupted by pedoturbation and erosion, and after most organic constituents have long since weathered away, the rocks remain to signify the technology and behavioral pattern.

This article seeks to explain fundamental concepts necessary to recognize, understand, and effectively investigate earth ovens in the archaeological record. We argue that most closely spaced arrangements of heated stones, including many "hearth" features, as well as most substantial accumulations of spent cooking stones are manifestations of a single technology: earth oven cookery. Although earth ovens have been ethnographically documented in many different settings, earth oven technology and its archaeological signatures remain understudied and lack a unifying nomenclature equivalent to lithic and ceramic technologies or soil formation processes. ${ }^{3}$ Improving this circumstance is our prime objective. Inadequate knowledge about how earth ovens function, coupled with an absence of a unifying terminology, hinders interregional approaches and impedes spatial and temporal comparisons of these pervasive cooking facilities. Reliable comparative approaches have long been integral to land-use and dietary studies and more recently in assessing status, gender, feasting, and sundry other food-related issues (e.g., Goodale 
et al. 2004; Hayden and Dietler 2001; Lepofsky et al. 2009).

Our perspective stems from more than three decades of field and analytical experiences and our common interest in learning about how earth ovens function and how their nature, distribution, and antiquity might better inform us about huntergatherer behavior in western North America (e.g., Black et al. 1997; Thoms 1989). Both of us first excavated and analyzed earth ovens in the late 1970s (e.g., Black and McGraw 1985; Thoms et al. 1981); we continued to do so throughout our cultural resource management careers (e.g., Black 2003) and to the present from academic settings (e.g., Thoms 2009). We, along with many of our colleagues, have often referred to these features as hearths and burned rock concentrations or by other generic functionless terms, which we argue is a practice that inhibits understanding.

\section{Research Context}

The modern human digestive tract necessitates consistent intake of cooked foods (Wrangham 2009). Cooking technology has become more costly through the millennia as foods that require prolonged baking are added to the diet and as greater proportions of available calories are extracted from meat and other foods by boiling (Thoms 2009). Compared with short-term cooking over direct flames and on/in hot coals, prolonged baking in earth ovens with rock heating elements renders more of the inherent calories in a given food readily digestible. Worldwide similarities in earth oven cookery result from plant and animal tissues with comparable biochemical properties responding in parallel fashion to the application of heat and moisture (Wandsnider 1997). The advent and proliferation of earth ovens have been argued to be an indicator of intensification-directed dietary changes and human evolution, via increased consumption of fat and easier-to-chew meat in cold environments (e.g., Brace 2005) and of complex carbohydrates in temperate settings (e.g., Leach et al. 2006; Thoms 2008a).

Earth ovens were in use by 35,000-31,000 years ago in Europe (Movius 1966; Straus 2006), Japan (Dogome 2000), Australia (Gillespie 1997), and the Bismarck Archipelago (Torrence et al. 2004). Their use in the New World, including on the Edwards Plateau of central and southwest Texas, was under way by some 10,000 years ago (Black et al. 1998:82-84). Across western North America, earth oven cookery intensified substantially between 4,000 and 2,000 years ago (Thoms 2009). Many earth ovens in the western part of the continent have yielded charred underground storage organs; geophytes, especially Liliaceae and Alliaceae family bulbs (e.g., camas and onions); and ground-level Agavaceae family rosettes (i.e., "heads" or "hearts"), notably those of the desert succulents agave and sotol (Dering 1997, 1999, 2004; Thoms 1989, 2008a).

Thoms (2003) argues that continent-wide, punctuated increases in the usage of rock heating elements during the Holocene resulted primarily from population packing and related intensification of broad-spectrum foraging. Accordingly, the spatiotemporal distribution of earth ovens in a given region serves as a useful and testable measure of land-use intensification (e.g., Ames 2005; Goodale et al. 2004; Lepofsky and Peacock 2004). Said differently, proliferation of earth oven technology indicates a major intensification-oriented dietary shift during the early Holocene, which Thoms (2008a) terms the onset of preagricultural carbohydrate revolutions. Hot-rockbased earth oven cookery is significantly more labor intensive than rockless cooking in hearths and pits (Dering 1999; Thoms 1989). The technology was first developed in the Old World after hundreds of thousands of years of open-flame and hot-coal cooking (Mentzer 2012). In the New World its archaeologically visible development coincides with a multitude of subsistence and land-use changes during the early Holocene. The integration of hot-rock cooking into subsistence strategies allowed hunter-gatherers to utilize a greater proportion of a given region's food-resource potential and afforded fuel-sparing and heat-conserving benefits, albeit via increased labor (i.e., intensification).

Remains of earth ovens with heating elements, by that and many other names, and their functional relationships to baking plant foods, are comparatively well recognized and investigated in several areas of North America, especially in the Pacific Northwest, Great Plains, and Southwest (e.g., Kludt 2006; Kramer 2000; Lepofsky and Lertzman 2008; Miller et al. 2011, Smith and Martin 2001; 
Thoms 1989; Wandsnider 1999; Wandsnider and Chung 2003; Yu 2009). The nature and distribution of earth ovens are also being studied in California as well (e.g., Milburn et al. 2009; Waechter 2005). Earth ovens are recognized as common features in the Ohio River basin (e.g., Pollack 2008) and elsewhere in the Eastern Woodlands (Benison 1999). Petraglia's (2002) study of "thermally altered stone features" highlights earth oven use in the Mid-Atlantic region. In the Southeast, earth ovens are widely reported from the Gulf Coastal Plain, where baked clay often served as a substitute for stone (e.g., Fedoroff 2009; Lewis 1988).

One of the best-known regional archaeological records of hunter-gatherer earth oven cookery is that of our case study area, the Edwards Plateau, at the continental intersection of the Southeast, Plains, and Southwest (e.g., Black et al. 1997). There the residuum of earth oven cookery is extraordinarily common and comparatively well studied. Yet only in recent decades have the region's archaeologists slowly come to understand the underlying technology and employ suitable nomenclature and investigative methodology.

While earth ovens were most common among hunter-gatherers, they were used by agriculturalists as well, especially in the Southwest to bake agave (e.g., Fish and Fish 1992; Miller et al. 2011; Sullivan et al. 2001; Whalen and Minnis 2009). Accordingly, the issues presented here may also resonate among archaeologists studying farming groups who baked wild and domestic plants in earth ovens. What makes the study of earth oven features especially informative and increasingly productive is that relevant and reliable frames of reference (cf. Binford 2001) are or can be readily established among (1) ecological factors that govern the productivity potential of given food resources in given areas, (2) cooking requirements and caloric yields of those resources, (3) the manner in which populations of the ethnographic era utilized cook-stone technology, and (4) the archaeological remains of earth ovens and associated features.

\section{Thermodynamics of Fires, Hearths, and Earth Ovens}

Functionally, all cooking-related fires can be said to have at least two main parts, a surface upon which a fire is created and the fire itself. The surface can be minimally prepared or elaborately so, flat or concave, and lined or unlined and may or may not be confined within a pit; ${ }^{4}$ such characteristics reflect function, context, and degree of reuse. Many archaeologically recognizable aboriginal cooking features have a third component, a layer of rocks that functions as a heating element and is typically placed atop or within the fire. The bed of hot rocks is usually covered by other layers, including moist green plant material and food baked by heat released from the rocks, and capped by an earthen lid to hold in the heat:

Heat has three singular and interesting properties that affect how it can be generated and used. The first and most important is intensity or temperature, which measures its ability to affect materials. The second is that heat flows constantly from a higher to lower temperature. The third is that it cannot be confined, since there is no known material that does not conduct heat to some extent. From the instant it is generated, heat leaks everywhere and constantly [Rehder 2000:9].

A small wood fire typically combusts relatively quickly and reaches temperatures of well over $500^{\circ} \mathrm{C}$. The temperature and duration of a fire are dependent on type, quality, and amount of fuel; the availability of oxygen; and how the fire is contained (or not). As fire burns, it heats the air, which expands, rises, and becomes "lost" to the atmosphere (diffused) unless the heat is confined or transferred to something in the immediate vicinity. Escaping hot air causes the fire to draw in more cool air, which repeats the cycle in the heating process known as convection.

Fires also radiate heat as thermal radiation (Siegel and Howell 2001). Infrared waves move through the air and only release heat when they strike a surface that can absorb them. This is what warms your hands when you hold them near a fire. In an enclosed space, such as inside a domestic structure, thermal radiation heats all of the exposed surfaces around a fire. An outside fire also provides warmth through radiation, but most of its heat is lost to the atmosphere. Fires built on flat surfaces or in shallow basins lose most of their heat quickly through radiation and convection. 
By containing or confining a fire, more of its heat can be directed toward whatever is being heated and used before it is lost. The simplest way to contain a fire is to build it in a pit. Dry sediment conducts heat very poorly because it is porous and made up of many tiny particles having a high surface to mass ratio. Sediment particles immediately adjacent to the fire heat quickly, but the heat flows slowly from particle to particle through conduction, making dry sediment a good insulator and container. Wet or damp sediment, on the other hand, readily loses heat through convection. As the moist sediment near the fire heats up, the moisture is converted to vapor, which dissipates heat and, through capillary action, draws more moisture toward the fire.

It is often desirable to store quickly the generated heat of a fire and release it more slowly in a controlled way. The most efficient and effective way to store a substantial amount of heat is to transfer it to a material with high thermal massthe ability to absorb, store, and release heat over time (Ataer 2006). Relative to water or unconsolidated sediment, rock has high thermal mass. A large rock is a superior thermal storage device compared with several smaller rocks of equal mass because it has less surface area relative to mass. Holding mass equal, rocks with smaller ratios of surface area to mass (like rounded cobbles) cool more slowly than those with larger ratios (such as thin slabs), and relatively dense, solid stones are superior to porous or fractured stones. Dense, solid rocks of any geologic origin absorb and hold heat reasonably well, releasing it slowly over periods of hours, or days, if properly insulated.

But thermal storage comes at a cost. Thermal cycling-heating and subsequent coolingcauses thermal stress and fatigue within any lithic material, eventually (or quickly) causing fracture and resulting in fire-cracked rocks (cf. Schalk and Meatte 1993). This disintegration, sometimes known as thermal stress weathering, is a familiar geological process in desert settings with pronounced diurnal thermal cycles. The factors that govern whether a rock of a given type, variety, or shape survives intense thermal stress weathering better than another are complex. While certain igneous rocks appear to survive thermal cycling better than most metamorphic and sedimentary rocks (Jackson 1998), overall, the archaeological record suggests that aboriginal cooks tended to use rock types at hand. Stark (2002) found that people who bake plants in earth ovens today look for relatively large rocks, small enough to easily manipulate by hand and of types not prone to explode or fracture quickly with repeated use. ${ }^{5}$ Ethnographically documented cooks often placed rocks directly on the fire or ignited the fire with the rocks amid the fuel. As anyone who tries to cook with heated rock soon learns, once the fire dies the uncovered rocks quickly begin to lose heat to the surrounding environment. This explains why most heating elements were insulated from conductive heat loss by being placed in a pit and insulated from convective heat loss by a cap of earth.

Heated rocks are not exclusively associated with earth ovens or even cooking (Ellis 1997; Thoms 2008b). An uncovered heating element gives up its dry heat relatively quickly, but this can be desirable. Certain foods can be cooked directly atop uncovered pavements of heated rocks sometimes known as griddles. Throughout most of North America rock heating elements were also used in pit-steaming foods, another form of moist heat, as well in steam baths (Driver and Massy 1957). Heated rocks can be removed from fires and used in other ways, perhaps the most important being stone boiling-cycling hot rocks through a contained liquid (i.e., wet heat). This cooking technology was widely documented in native North America and on every other continent (Driver and Massy 1957:227-230; Nelson 2010). We contend, however, that features representing griddles, steam baths, or stone boiling are far less common than the remains of earth ovens.

\section{Earth Oven Technology in Systemic Context}

The basic process of earth oven cookery is well understood through ethnohistorical accounts (e.g., Buckelew 1911:72-73; Castetter et al. 1938:2829, 45), ethnoarchaeological studies (e.g., Stark 2002), and experimentation (e.g., Dering 1999; Thoms 1989). In its moist-heat baking mode, a typical earth oven consists of seven layers (Figure 1), from bottom to top: (1) prepared surface (i.e., basin or deeper pit); (2) fire (reduced to glowing coals and ashes when oven is sealed); (3) layer of hot rocks; (4) lower layer of green plant mate- 
rial, which we call packing; (5) food being baked; (6) upper packing layer; and (7) earthen cap. ${ }^{6}$ The packing layers envelop the food, keeping it clean, supplying critical moisture, and adding flavor. Moist heat allows the food to undergo hydrolysis, during which complex molecules are broken into smaller, more easily digestible molecules (Wandsnider 1997). A moist-heat baking environment is also essential because, as long as adequate moisture from the packing material and food is retained in the oven (water is sometimes added), the temperature of the food remains below the phase change from water/liquid to steam/gas (ca. $100^{\circ} \mathrm{C}$ ) and thus prevents burning/charring the food (Stark 1997).

Earth ovens were specialized plant-processing facilities in many areas of temperate and subtropical North America, but they were also used to process meats, especially in more northern climes (e.g., Wandsnider 1997:13). In plant foods, hydrolysis cleaves complex modules such as long-chain carbohydrates (especially inulin) into simple short-chain sugars and degrades certain toxic compounds into nontoxic ones. The wide variety of inulin-rich wild geophytes (e.g., camas and onions) and desert succulents (e.g., agave and sotol) that served as food staples during the ethnographic era in western North America require baking for one-three days to liberate more of their inherent calories and detoxify. These and other long-baking plant foods became important because in predictable settings they were often abundant, readily accessible, and sustained longterm exploitation (Thoms 2008a). In the case of geophytes, family-size heating elements are ca. .5-1 $\mathrm{m}$ in diameter, whereas those ca. 2-3 $\mathrm{m}$ are for bulk processing (Thoms 1989, 2008b). In the case of the far bulkier desert succulents, familysize heating elements are ca. 1.5-2.5 $\mathrm{m}$ in diameter, whereas communal-scale heating elements can be well over $3 \mathrm{~m}$ in diameter (Dering 1999; Stark 2002).

As noted, earth ovens are fuel-sparing in that they conserve energy and do not require highquality fuel (Thoms 1989, 2003). Stark (2002:120) estimates that cooking agave bloom stalks in open fires requires at least four times more fuel than in earth ovens. He also points out that "extravagant" fuels such as seasoned hardwood are not essential-masses of soft woods, small branches, and dry leaves suffice to heat the rocks. In contrast, hardwood coals are highly desirable in open fires because they last longer and burn cleaner.

As per many ethnohistoric accounts and our own experiences building large ovens and baking plant foods, in firing a typical earth oven rocks are placed amid and atop a pile of fuel several feet thick, which is then ignited. This allows the rocks to be heated through radiation and convection; building the fire atop the rocks is far less efficient, convective heat being prone to rise. Adding cold rocks to an already-hot fire creates greater thermal stress, and rocks break apart more quickly than if heated more gradually as the fire builds. When the fire burns down and the rocks are hot, long wooden fire poles or tongs are used to arrange the rocks into the final form of the heating element. Then the packing, food, and earthen cap layers are added quickly, sealing in the moist heat. The sealed oven is typically left untouched for many hours or several days, depending on the quantity and nature of the food load.

When an earth oven is opened to remove the food, the layered arrangement is only partially dismantled. The earthen cap is pulled back along with the upper packing materials, and the food layer is removed, leaving the underlying packing material, heating element, and charcoal/ash layers and the lower part of the pit intact. The earth oven aftermath is an irregular pit surrounded by an arcing mound of earth and decaying plant remains. Weathering follows as rain, wind, animals, and plants rework the baking residue. Organics decompose, quickly or slowly depending on the environment. Plant roots seek out the organicrich, moisture-holding trap formed by the abandoned oven pit. And a trap it is. Things fall or wash in, and the depression beckons refuse. As it makes for a convenient trash pit, all manner of detritus unrelated to oven baking may be discarded there, including animal bones, plant parts, flaking debris, and spent tools.

An abandoned oven pit might sit for months, years, or even decades before it is reused for its original purpose. But it is a recognized place, a facility that will likely be reused for its original purpose unless nature intervenes and conceals it. In upland settings earth oven facilities are "persistent places" (Schlanger 1992), especially those constructed amid shallow soils on nonaggrading 
landscape surfaces where pits are difficult to dig and sediment is hard to come by. There, the abandoned oven pit settles and fills in ever so gradually, remaining as a visible depression for centuries. In alluvial settings and on hillside toe slopes, oven pits do not remain visible as long, especially in active floodplain settings where they may be sealed by layers of fine-grain flood sediments. We can expect that in such contexts oven facilities were likely reused only if people returned to build an oven within months or a few years, while the pit and reusable rocks were still apparent.

\section{Earth Oven Technology in Archaeological Context}

Earth oven facilities are accretional accumulations resulting from dynamic behavioral cycles: (1) oven pits dug and redug, (2) ovens built and rebuilt, (3) borrow pits dug and expanded, and (4) new construction materials added. Some additions are partially reusable (rock and earth); others are expendable (fuel and packing). Added materials are ordinarily destroyed or broken down over several use cycles and incorporated into the deposits by a combination of fire, mechanical action (e.g., digging), biological processes, and chemical weathering. As for the food load, the edible portion is removed and often undergoes additional processing such as drying and pulverizing, while the inedible parts (e.g., outer leaves) are discarded and added to the palimpsest or used for other purposes (e.g., fiber extraction). As noted, with time oven pits often become convenient trash pits. Small wonder that the resulting archaeological evidence is difficult to parse.

As amply demonstrated in North American ethnohistoric and ethnographic accounts, many variations are known on the earth oven theme (e.g., Ellis 1997:66-76; Kludt 2006:59-77; Thoms 1989:394-405; Yu 2009:37-79), and it is to be expected that over the last 10 millennia there were many more variants. In archaeological contexts it is often difficult to sort out variation caused by differences in targeted food resource, oven design, processing scale, depositional context, preservation conditions, and so forth. Even at a single point on the landscape, ovens were not necessarily constructed in the same way during each use episode or used to bake the same foodstuffs. Over time and across the wider landscape there is a great deal of as-yet-unexplained variation in the archaeological record of earth oven technology, but this should not stand in the way of recognizing and understanding basic patterns. The varied archaeological patterns generated by earth oven processing are sometimes difficult to recognize, investigate, and interpret for interrelated reasons, including the following: (1) Oven locales are often reused, sometimes hundreds of times over spans of centuries or even millennia, forming substantial processing facilities; (2) oven facilities are palimpsest deposits in which the evidence of earth oven baking may be commingled with refuse from unrelated activities that predate and postdate oven use; (3) the remains of individual ovens and oven facilities are often found in upland and deflated depositional contexts with poor organic preservation and little or no stratification.

\section{The Earth Ovens of the Edwards Plateau}

The challenge of recognizing and effectively investigating the archaeological signatures of hunter-gatherer earth oven technology is illustrated by the archaeological record of our study area. Truly extraordinary quantities of heated limestone were used and discarded by huntergatherers in central and southwestern Texas upon and near the vast uplifted Cretaceous limestone expanse known as the Edwards Plateau (Figure 2). The greater Edwards Plateau was home to foraging peoples who were well established in the eastern plateau by Clovis times (Collins 2004). The region's archaeological record is dominated by evidence of hunting and gathering societies spanning the final 10,000 years before European intrusion. Agriculturally based sedentary societies were never established. Overall, we can reasonably characterize the entire prehistoric record of the region as that of foraging peoples living Archaic lifeways. Earth ovens first appear by $8000-7500$ B.C. and are increasingly characteristic of the archaeological record from then on (Black and Creel 1997; Black et al. 1998; Collins 1998; Thoms 2008b).

The most prominent and durable remains in the region's archaeological record are massive, mounded accumulations (ca. 5-50-plus tons, 820-plus $\mathrm{m}$ in diameter, and .5-2.0 $\mathrm{m}$ in thickness) 


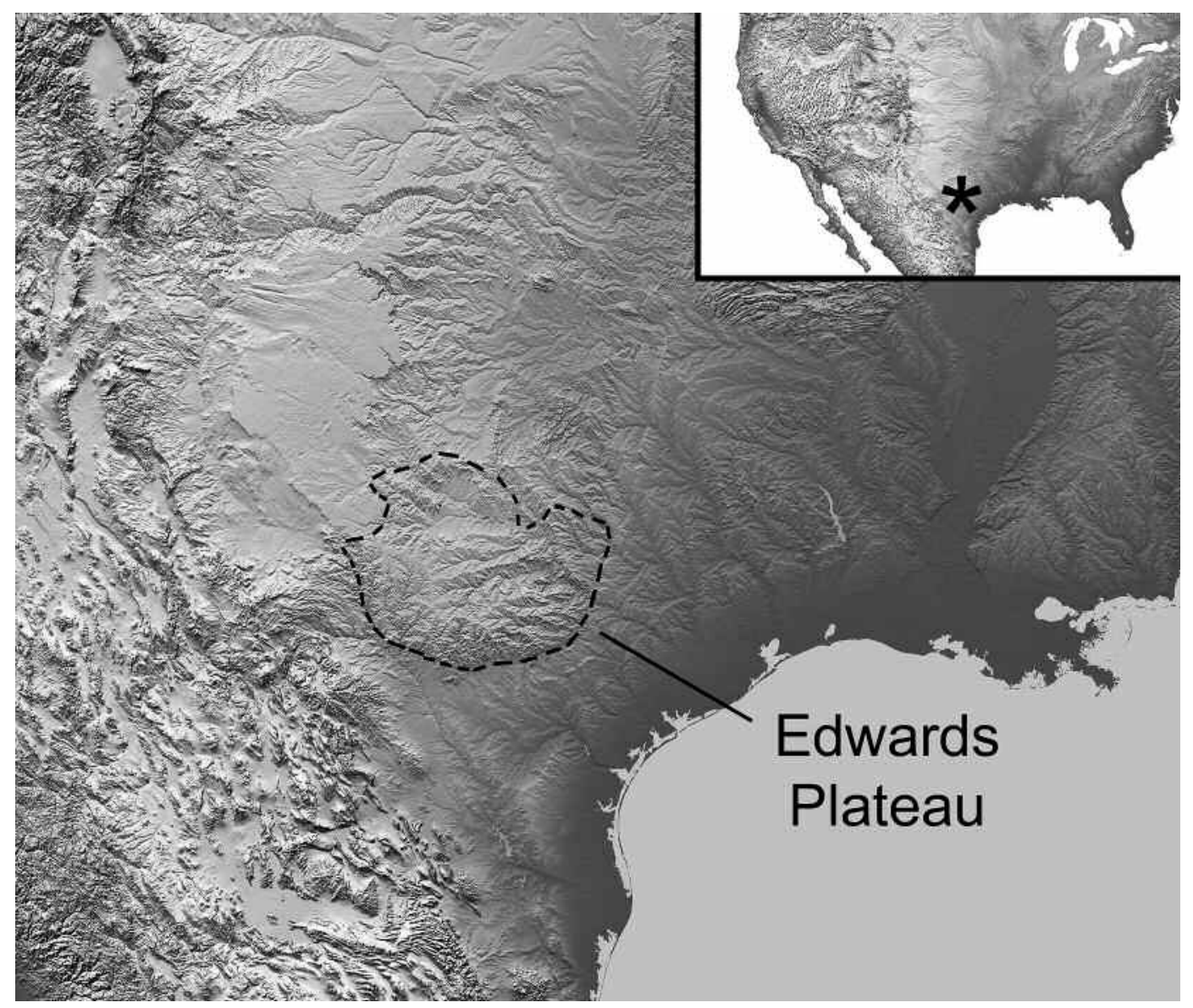

Figure 2. Location of study area: (a) in North America; (b) in south-central North America (base map NASA/Jet Propulsion Laboratory).

of fire-cracked limestone known as burned rock middens or mounds (BRMs). Within most middens, often near their centers, are remnants of what generations of archaeologists called hearths: basin-shaped patterns (ca. 1-3 $\mathrm{m}$ in diameter) of relatively large and minimally fractured rocks surrounded and enveloped by fist-sized and smaller FCR fragments amid carbon-stained sediment (Figure 3). Although BRMs were long recognized as cooking-related accumulations, the formation process(es) and targeted resources puzzled archaeologists for decades (Hester 1970, 1991; Kelley and Campbell 1942).

We realize today that the so-called hearths within burned rock middens represent the heating elements of earth ovens used primarily to transform a variety of geophytes and desert succulents into edible foodstuff (Black et al. 1997; Mauldin et al. 2003; Mehalchick et al. 2004). In other words, BRMs are specialized earth oven facilities where dozens to hundreds of ovens were built. Compilations of more than 150 radiocarbon assays from several dozen BRMs show that the use of BRMs peaked between ca.A.D. 800 and 1500, although earlier dates are likely underrepresented due to preservation bias (Black and Creel 1997:271-284; Mauldin et al. 2003:165-173).

Three interrelated investigative developments were keys to identifying BRMs as earth oven facilities. First was the recognition that the "center-focused" structural pattern of ring middens in the southwestern plateau long thought to be sotol- and agave-roasting pits (e.g., Wilson 1930) was shared by the often larger and sometimes dome-shaped BRMs of the central and eastern plateau (Black and Creel 1997:284-290). With adequate excavation exposure, especially through cross-trenching, BRMs across the region were 


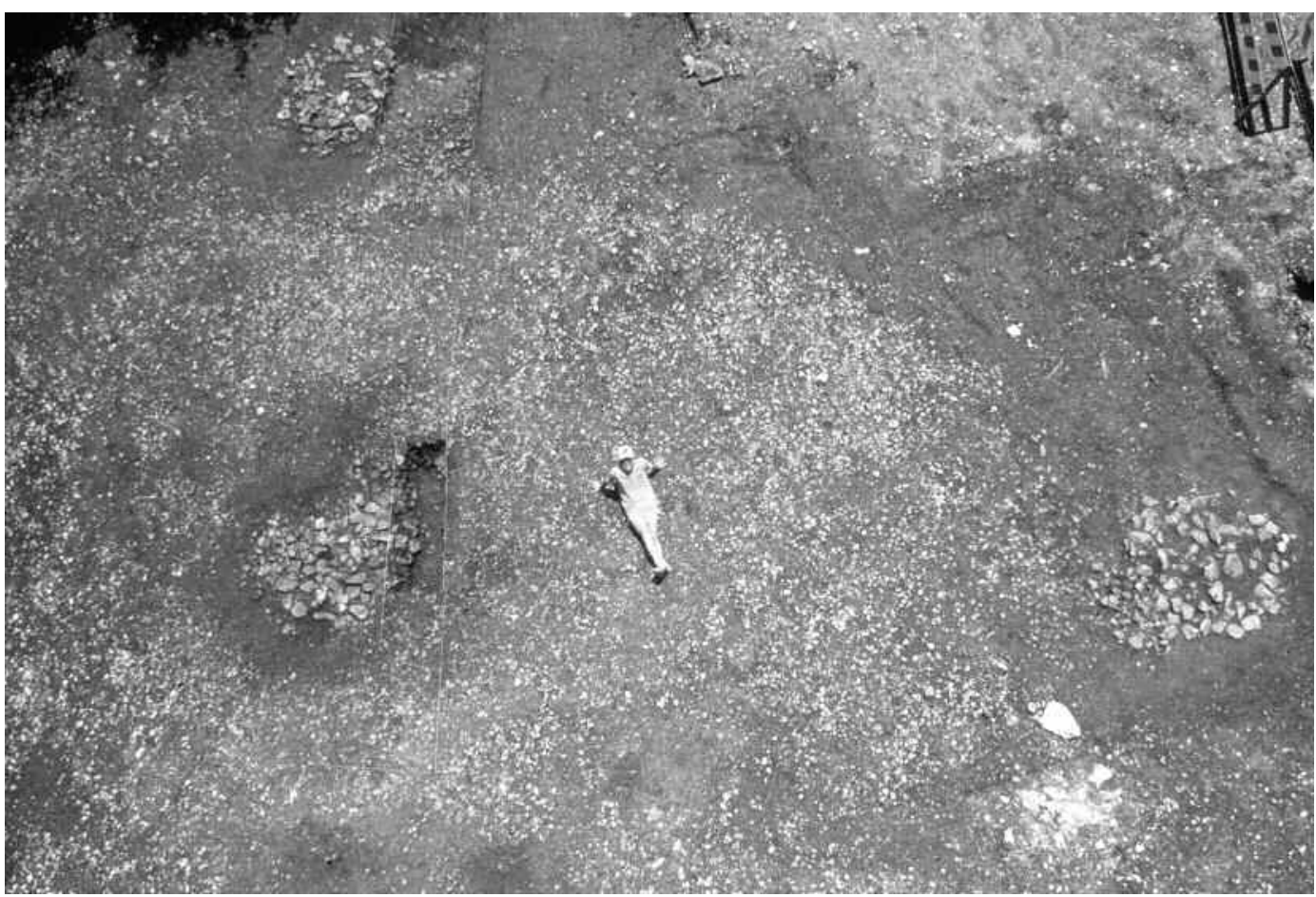

Figure 3. Earth oven facility (burned rock midden) with three visible circular heating elements, including one in a central oven pit marked by intense carbon staining and two others just outside the ring-shaped accumulation of discarded firecracked rock (Higgins site, 41BX184; photo by Stephen L. Black).

seen to have distinct centers with intense carbon staining, within which were concentrations of relatively large FCR. The central areas vary from subtle to obvious depressions and are surrounded by ring-shaped accumulations of smaller FCR. Second was gaining an understanding of earth oven technology through ethnohistoric and ethnographic accounts and hands-on actualistic experiments (e.g., Dering 1999; Jackson 1998; Stark 1997; Thoms 1989, 2008b). Third was a concerted effort to recover and identify charred macrobotanical remains from BRMs, especially those found in association with central features, through the use of flotation (e.g., Mehalchick et al. 2004). Although fragments of charred fuelwood can be recovered from most BRMs, charred food remains and packing materials are recovered far less commonly because of preservation factors, recovery methods, and the fact that charred food represents a cooking accident, not the norm. Over the past several decades a growing variety of geophytes has been identified in the central and eastern plateau, while desert succulents are most com- mon in the southwestern plateau (e.g., Dering 1997, 1999, 2004). Collectively, these developments and related studies have allowed us to grasp the basic patterns of earth oven cookery on and near the Edwards Plateau.

At thousands of hunter-gatherer sites across the greater Edwards Plateau and in all directions beyond, comparatively isolated rock-defined features routinely termed hearths are found in contexts where substantive BRMs did not form (Figure 4). We contend that most of these represent individual single-use or limited-reuse examples of the same cooking technology. ${ }^{7}$ Across the region the archaeological remains of earth oven cookery constitute a morphological spectrum extending from isolated rock heating elements and remnants thereof resulting from single-use ovens to extensive accumulations of FCR and carbonstained sediment signifying long-term facilities where dozens to hundreds of ovens were built over spans of centuries and even millennia (e.g., Black and Creel 1997:278; Boyd et al. 2004:131; Mauldin et al. 2003:167). Most oven locales lie 


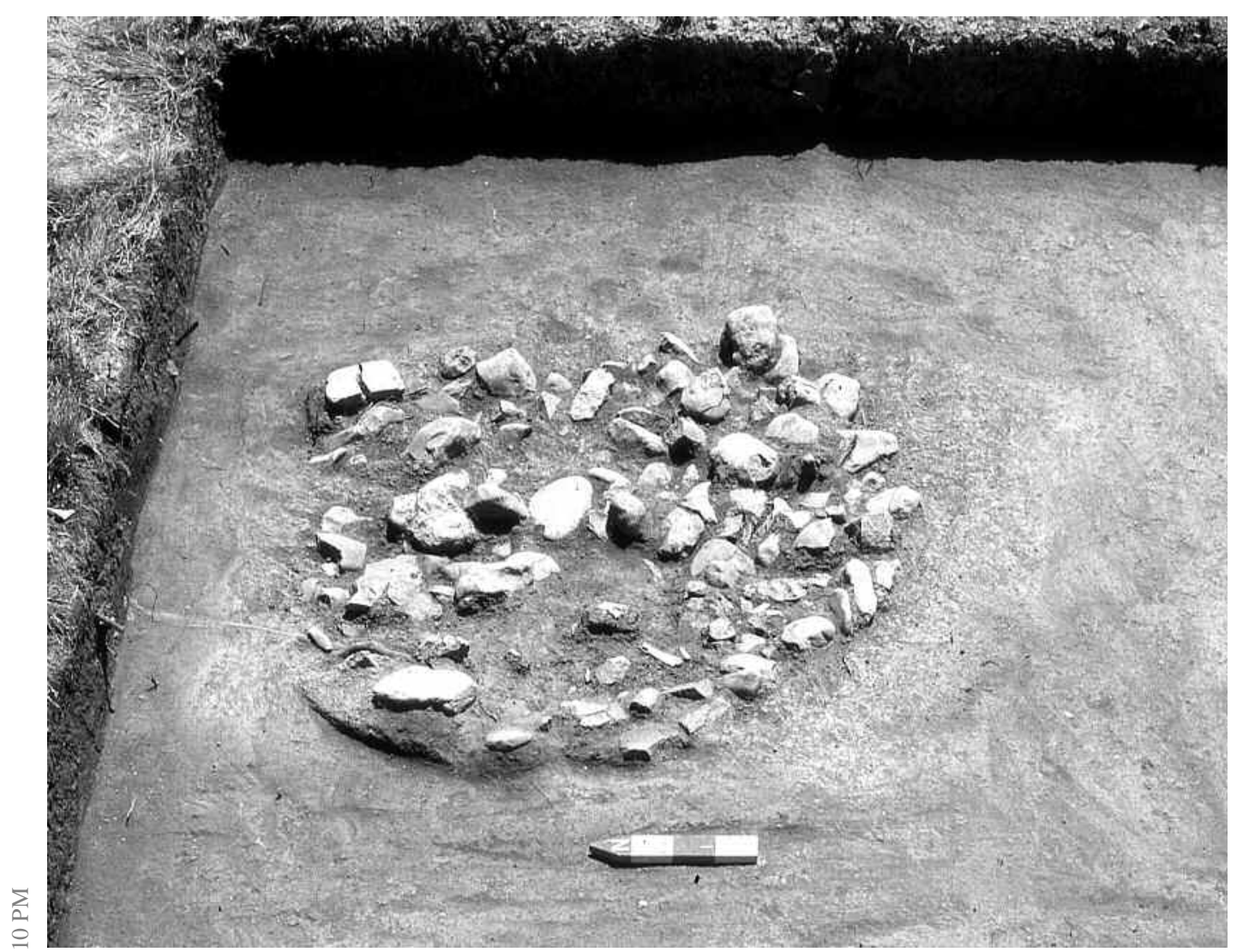

Figure 4. Isolated "hearth" feature consisting of an obvious heating element within a sharply defined oven pit marked by carbon-stained sediment (Buckhollow site, 41KM16; courtesy Texas Archeological Research Laboratory, University of Texas at Austin).

somewhere between these extremes. Nonetheless, it is helpful to distinguish between an earth oven as an individual construction and an oven facility (e.g., a BRM) as a locale where multiple earth ovens were constructed in intermittent succession.

\section{Archaeological Signatures of Earth Ovens}

The signatures of the earth ovens of the Edwards Plateau are instructive. The heating element and oven pit can be thought of as primary feature components, as are carbon-stained and thermally oxidized sediments. When preserved, these form a cohesive pattern readily identifiable as the remains of an earth oven. Ideal contexts, however, rarely prevail. Far more common are what we consider secondary feature components, such as discard scatters and remnants of heating elements and pits. These less obvious components are often not appreciated for what they are, especially when only partially exposed sans organic evidence.

Earth oven facilities go through predictable developmental permutations. They start as the scene of a single oven construction. As the facility is reused, its archaeological footprint expands over a larger area and includes numerous commingled feature components such as ever-growing FCR accumulations, heating element remnants, cleanout piles, and irregular pit interfaces (cf. Thoms 1989:399, 2009). It is useful to consider the signatures of earth oven components individually.

\section{Heating Elements}

The most easily recognized earth oven signature is that of an intact heating element (Figures 4-6). These "oven bed" patterns of closely spaced and relatively large burned rocks are usually circular 


\section{AREA 1 \\ FEATURE 1}
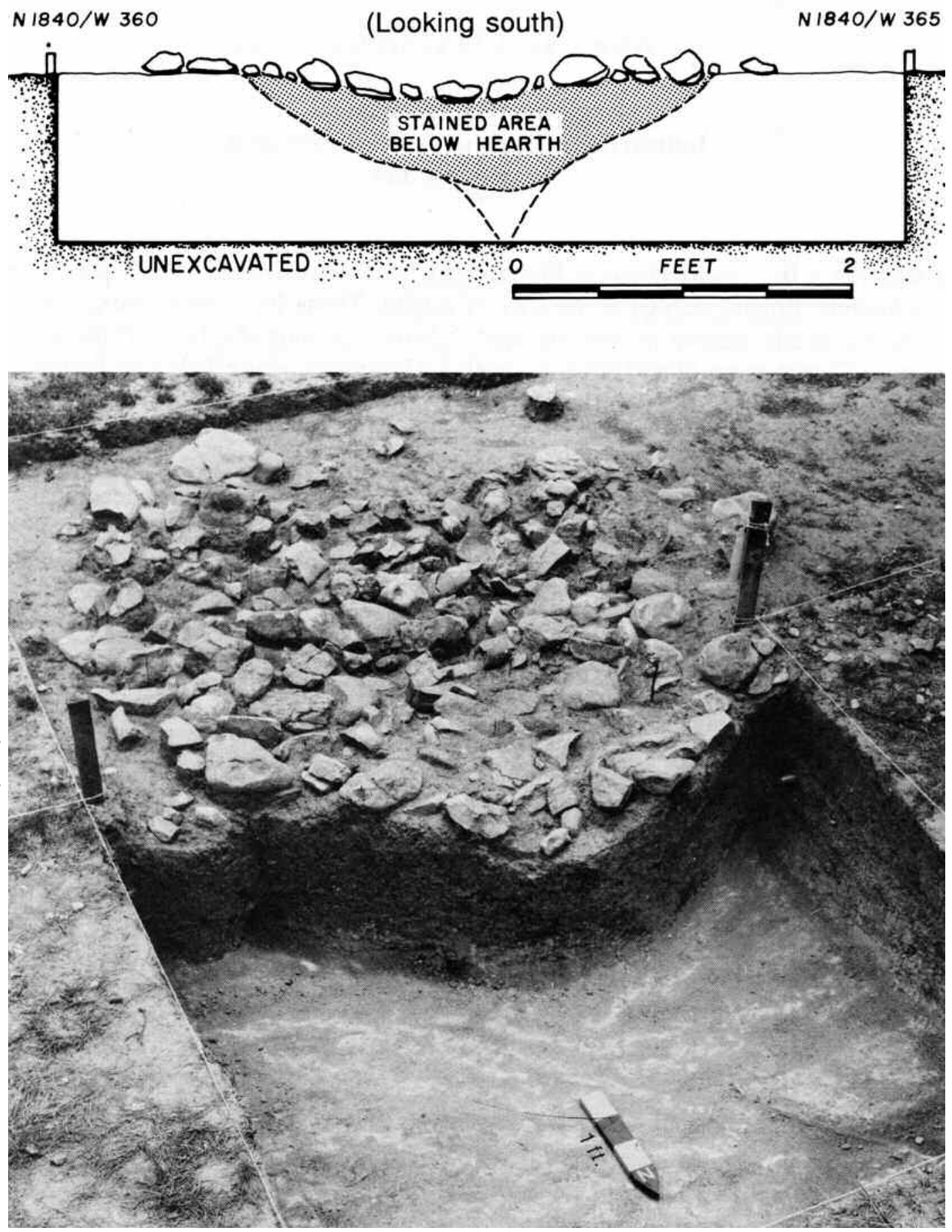

Figure 5. This rock "hearth" is a clear example of a small earth oven facility with carbon staining underlying a heating element (Buckhollow site, 41KM16, Johnson 1994:Figure 11; courtesy Texas Historical Commission). 


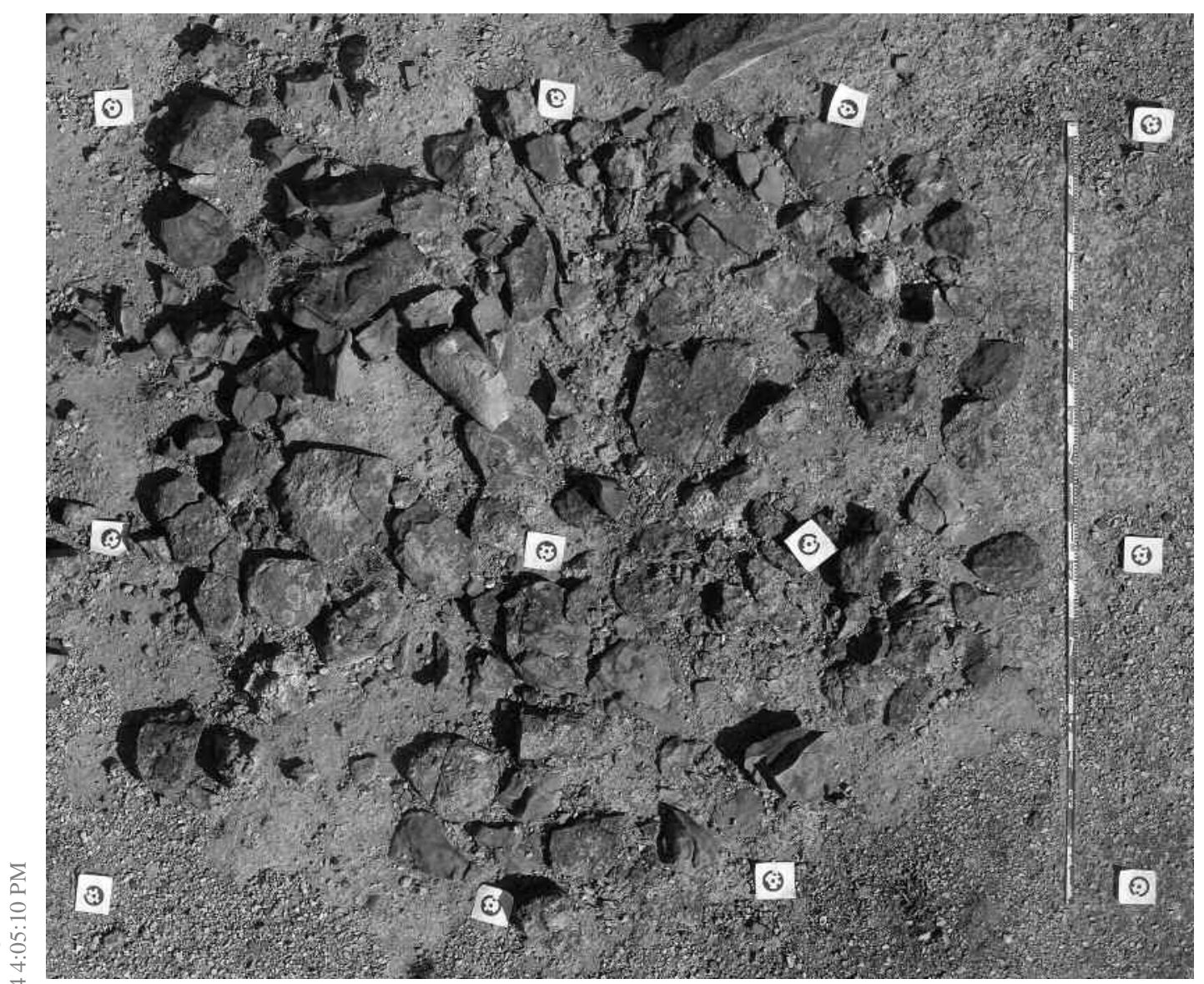

Figure 6. Large (2-m-diameter) single-use heating element exposed on the surface at the Painted Canyon Flats site (41VV448). Cross section revealed a thin layer of fuelwood charcoal directly beneath the rocks; three accelerator mass spectrometry assays strongly overlapped at one sigma (courtesy Ancient Southwest Texas project, Texas State University).

to oval in outline (Black 1997). In favorable preservation conditions, intact heating elements are directly associated with evidence of fire and intense heat (ca. $500-900^{\circ} \mathrm{C}$ ) such as charred plant remains, ash, carbon-stained and thermally oxidized sediment, and FCR. Relative to discarded "spent" cooking stones found in secondary feature components, rocks making up oven heating elements are significantly larger in size, less fragmented, and fractured in place. When large stones were used, heating elements are often a single rock thick, but those composed of smaller stones may be two or three rocks thick. In cross section, typical heating elements form a lens with concave upper and lower surfaces, a consequence of being contained within a basin-shaped pit. Flat heating element lenses are not uncommon, especially in surficial features, but must be viewed critically. Flat profiles can result from deflation-over time heating elements become lag deposits no longer in their original vertical position, although the horizontal arrangement may be relatively unaltered.

Heating elements vary considerably in scale, from as little as $.5 \mathrm{~m}$ across to more than $3 \mathrm{~m}$ in diameter. The larger examples (ca. 1.5-3-plus $\mathrm{m}$ diameter) are likely to be recognized for what they are simply because they are too big to be considered ordinary hearths and there are few other viable explanations for large circular arrangements of FCR. We contend, however, that the more common smaller heating elements (ca. .5-1.5 m diameter) are also prime candidates for earth oven beds, although stereotypically these are deemed hearths. 


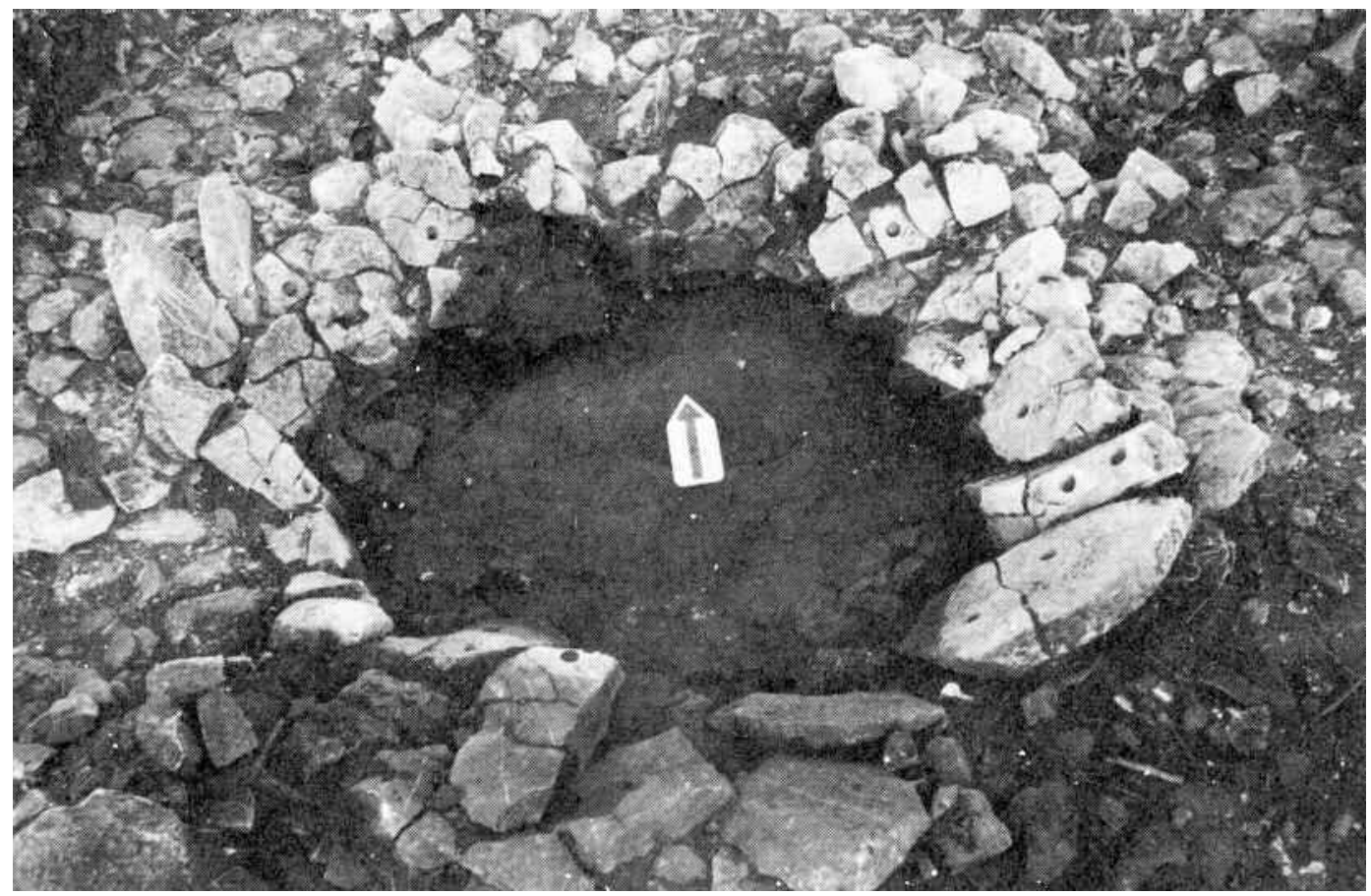

Figure 7. Large slab-lined earth oven built within a relatively deep, steep-sided pit. Archaeomagnetic samples were removed from the small circular drill holes. Magnetically oriented core samples revealed that most of the rocks had cooled in place from temperatures in excess of $500^{\circ} \mathrm{C}$ (Mustang Branch site, 41HY209M, Ricklis and Collins 1994:Figure 43; courtesy Texas Archeological Research Laboratory, University of Texas at Austin).

\section{Heating Element Remnants}

Excavations at many sites encounter segments of once-intact heating elements that were truncated by the construction of later ovens, partially robbed of useful rocks, or disrupted by various other formation processes. These remnants can appear as clusters of several relatively large adjacent rocks with a similar vertical orientation. In well-preserved contexts they are often partially enveloped by carbon-stained sediment and directly overlie charcoal. In isolated nonmidden contexts, heating element remnants may be readily visible, but often they are equivocal - a suggestive arrangement but not enough of a pattern to confidently identify, particularly in the absence of organic evidence.

\section{Oven Pits}

Many oven pits are shallow basins, although some are deep, steep-sided pits that may be lined with stones (Figures 7 and 8). In open unconstrained settings with deep unconsolidated sediment such as sandy loam, oven pits are easily dug and may be used for only a single oven. But oven pits often develop into long-term facilities, particularly in (1) settings where pits are hard to create because of shallow soils, indurated sediment, or bedrock; (2) logistically ideal locales near resource concentrations (e.g., floodplains, meadows, and canyon heads); and (3) favored residential sites where oven facilities are likely to be situated in peripheral areas outside of primary living areas. With reuse, oven pits become littered with, and ringed by, earth oven debris, within which numerous secondary oven components may be present.

In plan view, intact oven pits usually appear as circular carbon-stained areas within which heating elements and remnants are present. In many depositional circumstances, especially shallow or sandy upland soils, pit interfaces are difficult or impossible to discern except inferentially by the contours of the surfaces upon which oven rocks rest. In contrast, oven pits dug into clayrich sediment on rapidly aggrading landforms may have remarkably well-preserved and easy- 


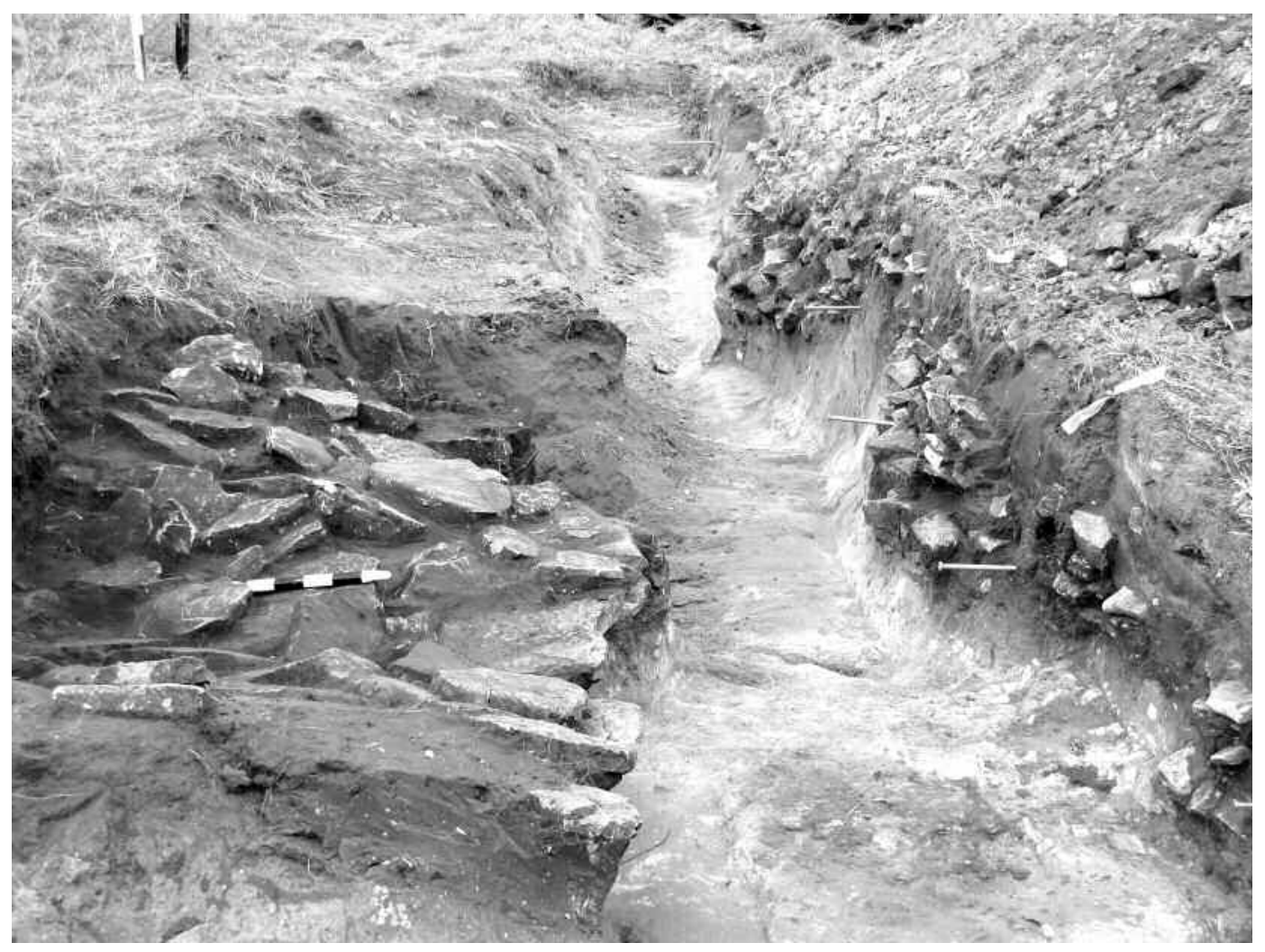

ב.

Figure 8. Earth oven facility (burned rock midden) with multiple visible ovens. On the left is a large central oven pit marked by carbon-stained sediment and several superimposed slab linings. On the right two oven pits can be seen in profile, the basin-shaped pits marked by large heating-element rocks, intensive carbon staining, and partial infilling by discarded fire-cracked rock (41CV594, Fort Hood; photo by Alston V. Thoms).

to-read signatures. In such circumstances, oven pits are often filled with carbon-stained sediment, and the pit interfaces may be clearly defined by oxidation rinds and occasionally by fine laminae of ash and charcoal. But even in clay soils, pit interfaces become diffuse over time due to pervasive pedoturbation processes.

\section{Pit Linings}

Rocks were sometimes used to line the pit prior to a fire being built (Figures 7 and 8). Where available, relatively flat "slabs" of tabular stone were chosen for this purpose instead of cobbles or irregular clasts. We hypothesize that pit linings were constructed primarily to function as moisture barriers, although stone linings also store heat. True pit linings were carefully arranged such that the rocks form a continuous, bowl-shaped surface, sometimes with steeply sloping walls and a flat floor. The characterization "stone-lined" is often erroneously applied to pits where heating elements have simply settled to the bottom when no longer supported by the fuel layer. In favorable conditions, a telltale difference is whether charcoal and evidence of thermal oxidation are found directly beneath the rocks, which would not be the case with intentional linings. Another indicator is whether the most oxidized (e.g., reddened) rock surface is on the top or the bottom, indicating the direction of applied heat. Stone-lined oven pits may also contain a second layer of rocks above the lined floor that functioned as the main heating element.

\section{Carbon Staining}

Dark, carbon-rich anthrosol is characteristic of earth oven cookery (Figures 3-5 and 7). Ovens tend to be sealed while substantial amounts of glowing embers and incompletely combusted fuel remain beneath and amid the heating element. 
This creates a reduction atmosphere in which the oven components become coated in soot. While continuing to slowly combust, the fuel directly below large rocks may be smothered, becoming charcoal. In marked contrast, in an open fire the fuel is typically combusted and reduced to ash. Although charcoal breaks down over time via chemical weathering and bioturbation, carbonstained sediments persist long after most macroscopically visible charcoal deteriorates. All else equal, the intensity and extent of carbon staining should be proportional to the number of baking episodes that transpired in a given facility. Intensively used oven facilities are often said to have distinctive blackened "midden soil." Of course, the intensity of carbon staining also reflects age and sediment characteristics.

\section{Discarded Fire-Cracked Rock}

Spent cooking stones constitute the most archaeologically visible signature of often-used earth oven facilities (Figure 3). ${ }^{8}$ When an oven pit is reused, the heating element must be rebuilt, typically from a combination of serviceable used rocks and pristine (i.e., new) cooking stones. In most cases the pit is cleaned out, thereby dismantling its existing heating element, and a new heating element is built therein (Figures 9 and 10). Sometimes a new heating element is built on top of the old one, resulting in a single pit with superimposed intact heating elements. There are also oven facilities that appear to have pristine and still serviceable rocks stockpiled to one side of an oven pit for future use (Figure 11).

The cyclical process of oven cleanout and rebuilding resulted in the patterned discard of rocks too small or heavily fractured to be useful thermal storage components. ${ }^{9}$ Burned rock middens (Figure 3) are composed of literally tons of discarded fist-sized and smaller FCR. Many of the FCR concentrations around oven pits are probably spoil piles or cleanout scatters of spent cooking stones, recognizable by small rock size, high degree of fragmentation, a paucity of fractured-in-place rocks, and an irregular arrangement. If the oven facility is buried and retains its original vertical stratification, the spoils or rake-out piles around the pit should be at a somewhat higher elevation relative to the collapsed heating element in the center of the pit (Black 1997:263).

\section{Borrow Zones}

Given that substantial amounts of relatively finegrain sediment are required to cap ovens, the borrowing of sediment is an essential element of earth oven construction. Judging from our ovenbuilding experiences, effective earthen lids always require considerably more sediment than is yielded from a pit dug just large enough to hold an oven. Yet unequivocal evidence of borrow pits is rarely detected, apart from the oven pits themselves. Trenches dug through BRMs sometimes reveal overall bowl-shaped configurations. That is to say, midden deposits are deepest in the central pit area where heating elements and bed remnants are present, while the base of the outer midden deposits curves upward as if the entire feature, $10-15 \mathrm{~m}$ in diameter, formed within a large depression (e.g., Black et al. 1997:176). A parsimonious explanation is that as the oven facility was reused and more earth was required, the area immediately surrounding the oven pit was borrowed in a widening circle, gradually creating a large bowl-shaped depression that filled with discarded rock as the facility was reused.

Leach and Bousman (2001) call attention to the role that the borrowed sediment played in the formation of burned rock middens in the study area. They infer that sizable "borrow zones" existed around these earth oven facilities. Given that BRMs are often surrounded by preexisting and contemporary occupational deposits, the borrowing of sediment would have inadvertently introduced artifacts and ecofacts of varying ages into earth oven facilities. Borrowing, oven-pit digging, and related formation processes resulted in what Leach and Bousman term an "anthromantle" (2001:135), which characterizes dynamic deposits created by humans and subsequently eroded by natural processes (see also Leach et al. 2005). In other words, borrowing would have contributed to the palimpsest nature of earth oven facilities.

\section{Discussion and Conclusion}

Signatures of earth oven cookery abound in the archaeological record of south-central North America and many regions of the continent and world. Yet these signatures are often not recog- 


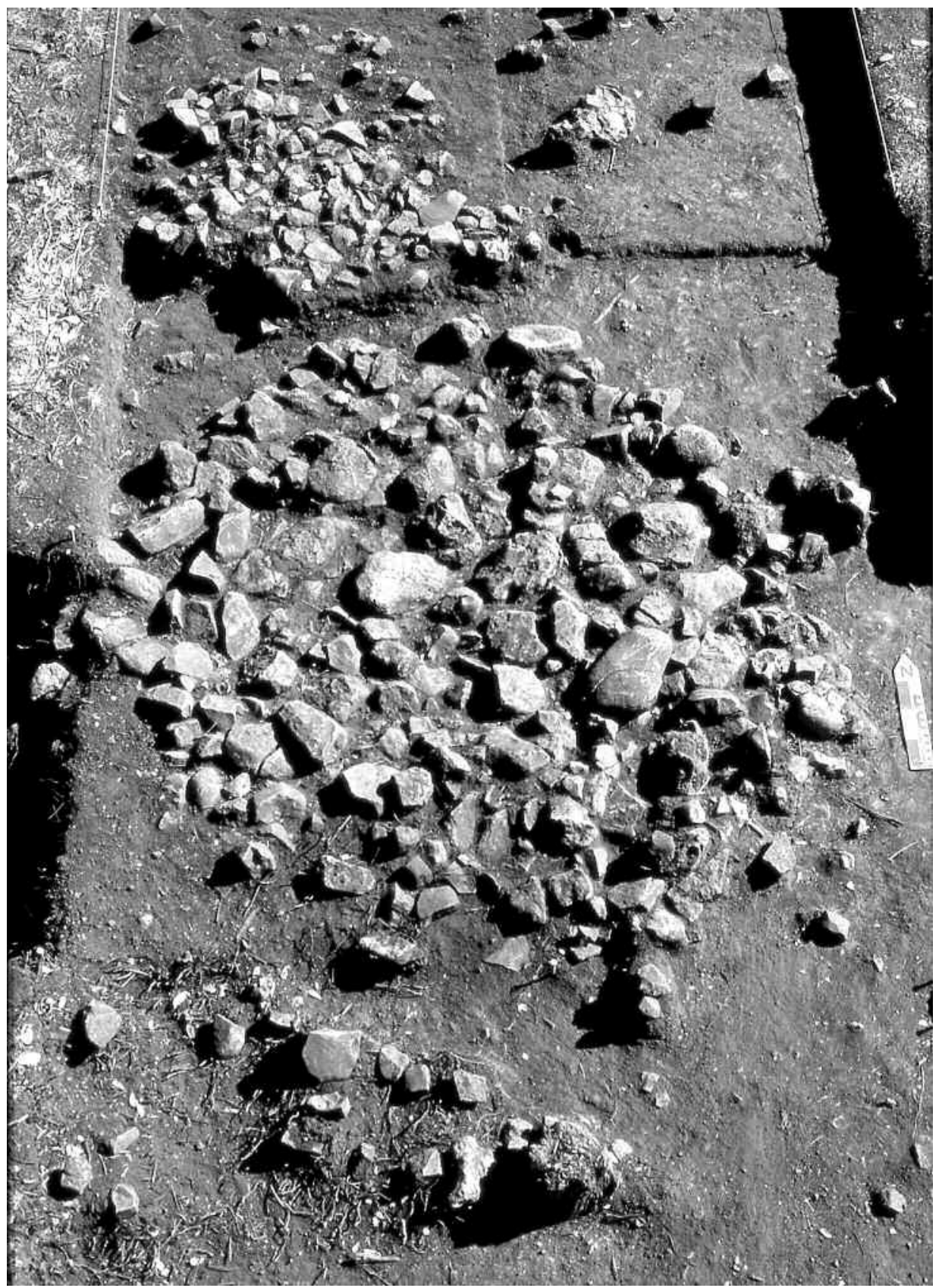

Figure 9. Circular heating element representing a "last use" even with the associated discard pile of smaller fire-cracked rock from earlier oven event(s) on one side and at a slightly higher elevation (Features 7 and 8, Honey Creek site, 41MS32; courtesy Texas Archeological Research Laboratory, University of Texas at Austin; cf. Black 1997).

nized for what they are. Many of us archaeologists do not understand earth oven technology, and we use confoundingly vague and varied terminology to describe what we encounter. We waste much time reinventing descriptive lexicons, focusing on only certain feature components, misconstruing palimpsest "associations," and reiterating the many ways that aboriginal peoples sometimes used heated rocks. Lamenting the fact that most individual FCR features do not have the preserved 


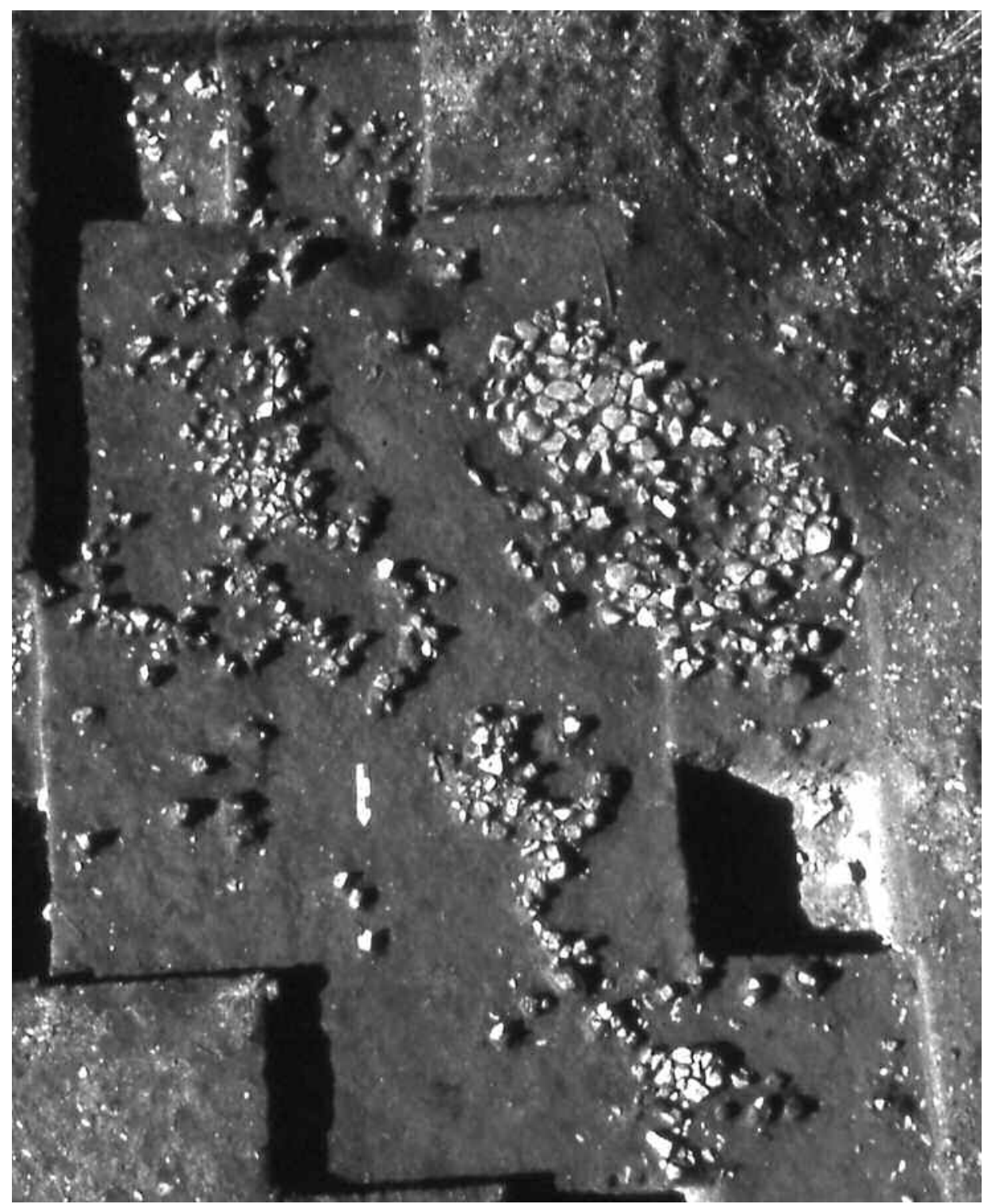

Figure 10. Earth oven facility with clear evidence of multiple use episodes. The "last use" event is represented by a circular heating element, ca. $1 \mathrm{~m}$ in diameter in the upper right, which intrudes into a substantial remnant of a larger basinshaped heating element that would have been more than $2 \mathrm{~m}$ in diameter. A circular carbon stain not visible in this photo suggests that a third oven pit had existed between the visible heating elements and adjacent the scattered arc of smaller fire-cracked rock (Features 2, 3, and 27, Honey Creek site, 41MS32; courtesy Texas Archeological Research Laboratory, University of Texas at Austin; cf. Black 1997).

potential to conclusively demonstrate exactly how they were used and what was processed, we often conclude little more than, "While it could be this or that, we will never really know." Or we put forth speculative resource-based explanations that fly in the face of the technological implications of the in-the-ground evidence.

When the archaeological signatures are viewed from a more holistic and technologically informed perspective, the prevalence of earth ovens becomes apparent. We reason that most arranged patterns .5-3-plus $m$ across of closely spaced, once-hot rocks represent the heating elements of earth ovens and that most disarticulated and amassed accumulations of FCR are the spent cooking stones thereof. This, in our opinion, should be a starting, testable 

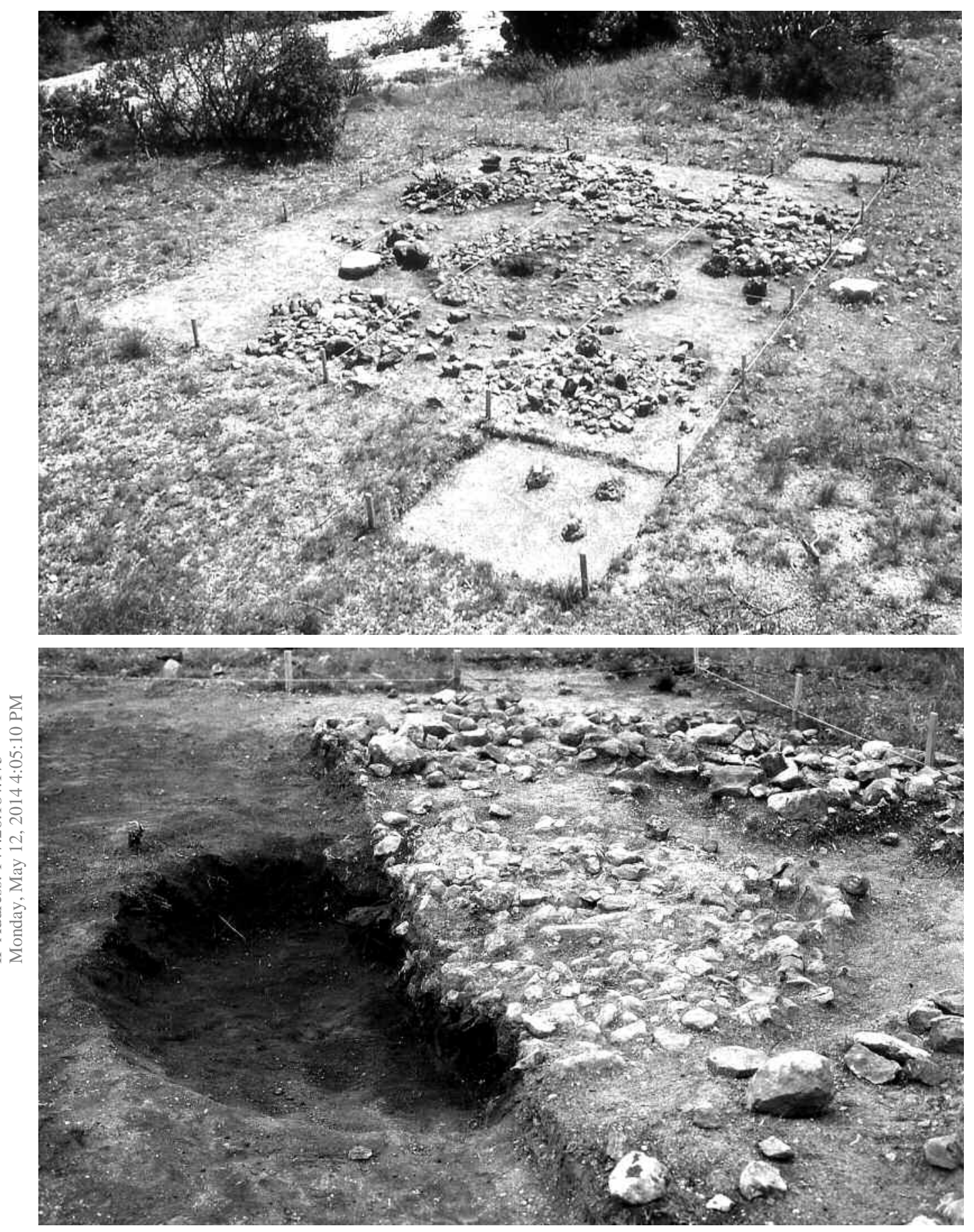

Figure 11. Early-stage, near-surface earth oven facility with central oven pit surrounded by opposing arcs of stockpiled unused rocks: (a) overview with the uppermost rocks exposed; (b) closer view after the central oven pit was cleaned out and sectioned. Within the large carbon-stained central oven pit were very large (ca. 30- to 50-cm) once-used rocks forming a lower heating element, overlain by tightly packed highly fragmented rocks, suggesting that the oven facility had been used several times (41CX131, Musk Hog Canyon; courtesy Texas Archeological Research Laboratory, University of Texas at Austin; cf. Luke 1983:Figure 35). 
premise when all such features are encountered. Earth oven technology is globally widespread, and it explains well the primary purpose of labor-intensive thermal storage. We do not maintain that all cooking features with stones are remains of earth ovens, but we infer that most of those with substantial quantities of heated stones are. Earth oven cooking allowed people to maximize caloric returns from plants that are otherwise inedible or minimally edible.

Given the inferred ubiquity of earth oven cookery and its implications for landscape use, we argue that in many areas of the world understanding earth ovens is critical to understanding huntergatherer lifeways. Toward that end we have explained the underlying thermodynamics, construction design, and life cycle of earth oven technology in systemic context. We have outlined how this technology is manifested in the archaeological record and defined a diagnostic nomenclature for the archaeological signatures of earth ovens. Our argument that most rock "hearths" are earth oven heating elements is not merely a semantic distinction. Across much of temperate North America most earth ovens were specialized plant-processing facilities and should be investigated and interpreted as such. They range in size from those used to bake a few dozen kilograms of geophytes for a single family to bulk-processing features for hundreds of kilograms of desert succulents for purposes of storage or feasting and other forms of communal consumption. The implications of such obviously significant variation within and between sites, across space, and through time merit far more scrutiny.

Given the palimpsest nature of all earth oven facilities, the poor organic preservation typical of most facilities and individual archaeological ovens, and the fact that burned food represents cooking failure, we cannot expect to find obvious smoking-gun evidence of precisely how most ovens were constructed and what was baked within. ${ }^{10}$ To recognize and accurately interpret patterns of earth oven cookery in a given area, one must consider combined evidence from numerous features and sites in conjunction with pragmatic comprehension of cooking technologies, the processing requirements of targeted resources, and postdepositional taphonomy.

Broad-stroke recognition of earth ovens for what they are is only a first step toward realizing their potential to inform us about spatial and temporal dimensions of hunter-gatherer subsistence practices, environmental and ecological dynamics, mobility, resource scheduling, social organization (e.g., feasting and gender issues), population stress, and other potentially relevant topics. Remains of earth ovens may be as ubiquitous as we claim, but recognizing and evaluating the evidence is challenging for stated reasons preservation, depositional context, overprinting, and postdepositional transformation processes, among others. This article explains the fundamental concepts governing earth ovens in the archaeological record. Perhaps this knowledge and diverse twenty-first-century analytical approaches will allow us to better understand earth oven technology and variation so that we can explain the roles earth oven processing played in foraging societies.

Acknowledgments. Support for this article came from the Departments of Anthropology at Texas State and Texas A\&M universities, the Texas Department of Transportation, and Prewitt and Associates, Inc., via the U.S. Army, Fort Hood, Texas, Cultural Resources Management Program. The present article benefited from formal comments by Jeffrey Boyer and two anonymous reviewers. Our arguments were also finetuned through discussions with fellow hot-rock enthusiasts Douglas Boyd, Phil Dering, and Karl Kibler, along with our graduate students Masahiro Kamiya, Charles Koenig, Laura Short, and Andrew Laurence. Helpful comments were also provided by reviewers of an earlier version of this article, including Jeffrey Leach and two anonymous reviewers. Kevin Jolly provided insightful critiques of several drafts.

\section{References Cited}

Ames, Kenneth E.

2005 Intensification of Food Production on the Northwest Coast and Elsewhere. In Keeping It Living: Traditions of Plant Use and Cultivation on the Northwest Coast of North America, edited by Douglas Deur and Nancy J. Turner, pp. 67-100. University of Washington Press, Seattle, and University of British Columbia Press, Vancouver.

Ataer, O. Ercan

2006 Storage of Thermal Energy in Energy Storage Systems. In Encyclopedia of Life Support Systems, edited by Yalcin Abdullah Gogus. Eolss Publishers, Oxford. Electronic document, http://www.eolss.net/ebooks/Sample\%20Chapters/C08/E3-14-02-00.pdf, accessed March 27, 2012.

Benison, Christopher J.

1999 Burned Rock Complexes, Baked Clay Objects, Steatite, and Ceramics: Evolutionary Implications for Plains/Eastern Woodlands Cooking Technologies. North American Archaeologist 24:287-317. 
Binford, Lewis R.

2001 Constructing Frames of Reference: An Analytical Method for Archaeological Theory Building Using HunterGatherer and Environmental Data Sets. University of California Press, Berkeley.

Black, Stephen L.

1997 Oven Cookery at the Honey Creek Site. In Hot Rock Cooking on the Greater Edwards Plateau: Four Burned Rock Midden Sites in West Central Texas, by Stephen L. Black, Linda W. Ellis, Darrell G. Creel, and Glenn T. Goode, pp. 255-268. Studies in Archeology 22. Texas Archeological Research Laboratory, University of Texas at Austin.

2003 Research Module 2: Studying the Hearths of the Greater Edwards Plateau. In Pavo Real (41BX52): A Paleoindian and Archaic Camp and Workshop on the Balcones Escarpment, South-Central Texas, by Michael B. Collins, Dale R. Hudler, and Stephen L. Black, pp. 375-405. Studies in Archeology 41. Texas Archeological Research Laboratory, University of Texas at Austin.

Black, Stephen L., and Darrell G. Creel

1997 The Central Texas Burned Rock Midden Reconsidered. In Hot Rock Cooking on the Greater Edwards Plateau: Four Burned Rock Midden Sites in West Central Texas, by Stephen L. Black, Linda W. Ellis, Darrell G. Creel, and Glenn T. Goode, pp. 269-301. Studies in Archeology 22. Texas Archeological Research Laboratory, University of Texas at Austin.

Black, Stephen L., Linda W. Ellis, Darrell G. Creel, and Glenn T. Goode

1997 Hot Rock Cooking on the Greater Edwards Plateau: Four Burned Rock Midden Sites in West Central Texas. Studies in Archeology 22. Texas Archeological Research Laboratory, University of Texas at Austin.

Black, Stephen L., James W. Karbula, Charles D. Frederick, and Charles G. Mear

1998 Archeology along the Wurzbach Parkway, Module 5: Testing and Geoarcheological Evaluation at the Number-6 Site (41BX996) and Other Sites. Studies in Archeology 29. Texas Archeological Research Laboratory, University of Texas at Austin.

Black, Stephen L., and Alfred J. McGraw

1985 The Panther Springs Creek Site: Cultural Change and Continuity in the Upper Salado Creek Drainage, South Central Texas. Archaeological Survey Report 100. Center for Archaeological Research, University of Texas at San Antonio.

Boyd, Douglas R., Christopher W. Ringstaff, and Gemma Mehalchick

2004 Analysis and Interpretations of Cultural Occupations at the Firebreak Site. In Shifting Sands and Geophytes: Geoarchaeological Investigations at Paluxy Sites on Fort Hood, Texas, by Gemma Mehalchick, Douglas R. Boyd, Karl W. Kibler, and Christopher W. Ringstaff, pp. 129 198. Research Report 48. Archaeological Resource Management Series, United States Army Fort Hood, Texas.

Brace, C. Loring

2005 "Neutral Theory" and the Dynamics of the Evolution of "Modern" Human Morphology. Human Evolution 20:19-38.

Buckelew, Francis M.

1911 Buckelew, The Indian Captive, or, The Life Story of F. M. Bucklew [sic]while a Captive among the Lipan Indians in the Western Wild of Frontier Texas, as Related by Himself. Written by S. E. Banta. Mason Herald, Mason, Texas.
Castetter, Edward F., Willis H. Bell, and Alvin R. Grove 1938 The Early Utilization and Distribution of Agave in the American Southwest. University of New Mexico Bulletin 335, Ethnobiological Studies in the American Southwest VI. University of New Mexico Press, Albuquerque.

Collins, Michael B.

2004 Archeology in Central Texas. In The Prehistory of Texas, edited by Timothy K. Perttula, pp. 101-126. Texas A\&M University Press, College Station.

Collins, Michael B. (editor)

1998 Wilson-Leonard: An 11,000-Year Archeological Record of Hunter-Gatherers in Central Texas. Studies in Archeology 31. Texas Archeological Research Laboratory, University of Texas at Austin.

Dering, J. Phillip

1997 Macrobotanical Remains. In Hot Rock Cooking on the Greater Edwards Plateau: Four Burned Rock Midden Sites in West Central Texas, by Stephen L. Black, Linda W. Ellis, Darrell G. Creel, and Glenn T. Goode, pp. 571600. Studies in Archeology 22. Texas Archeological Research Laboratory, University of Texas at Austin.

1999 Earth Oven Plant Processing in Archaic Period Economies: An Example from a Semi-Arid Savannah in South-Central North America. American Antiquity 64:659674.

2004 Analysis of Macrobotanical Remains from Three Paluxy Sites on Fort Hood, Texas. In Shifting Sands and Geophytes: Geoarchaeological Investigations at Paluxy Sites on Fort Hood, Texas, by Gemma Mehalchick, Douglas R. Boyd, Karl W. Kibler, and Christopher W. Ringstaff, pp. 245-257. Research Report 48. Archaeological Resource Management Series, United States Army Fort Hood, Texas.

Dogome, $\mathrm{H}$.

2000 Summary (in English). In Yokomine C Iseki (Yokomine C Site; in Japanese), edited by K. Sakaguchi and H. Dogome, pp. 1-2. Minami Tane Board of Education, Kagoshima.

Driver, Harold E., and William C. Massy

1957 Comparative Studies of North American Indians. Transactions of the American Philosophical Society, New Series, Vol. 47, Pt. 2. Philadelphia.

Ellis, Linda W.

1997 Hot Rock Technology. In Hot Rock Cooking on the Greater Edwards Plateau: Four Burned Rock Midden Sites in West Central Texas, by Stephen L. Black, Linda W. Ellis, Darrell G. Creel, and Glenn T. Goode, pp. 4381. Studies in Archeology 22. Texas Archeological Research Laboratory, University of Texas at Austin.

Fedoroff, Michael

2009 Earth-Oven Technology in the Mississippi Pine Hills: An Experimental Approach to Archaeological Investigations and Method Development. Unpublished Master's thesis, Department of Anthropology and Sociology, University of Southern Mississippi, Hattiesburg.

Fish, Suzanne K., and Paul R. Fish

1992 Prehistoric Landscapes of the Sonoran Desert Hohokam. Population and Environment 13:269-283.

Gillespie, Richard

1997 Burnt and Unburnt Carbon: Dating Charcoal and Burnt Bone from the Willandra Lakes, Australia. Radiocarbon 39:239-250.

Goodale, Nathan B., William C. Prentiss, and Ian Kuijt 2004 Cultural Complexity: A New Chronology of the Upper Columbia Drainage Area. In Complex Hunter- 
Gatherers: Evolution and Organization of Prehistoric Communities on the Plateau of Northwestern North America, edited by William C. Prentiss and Ian Kuijt, pp. 3648. University of Utah Press, Salt Lake City.

Hayden, Brian, and Michael Dietler (editors)

2001 Feasts: Archaeological and Ethnographic Perspectives on Food, Politics, and Power. Smithsonian Institution Press, Washington, D.C.

Hester, Thomas R.

1970 Burned Rock Middens on the Southwestern Edge of the Edwards Plateau, Texas. Plains Anthropologist 15:237250.

Hester, Thomas R. (editor)

1991 The Burned Rock Middens of Texas: An Archeological Symposium. Studies in Archeology 13. Texas Archeological Research Laboratory, University of Texas at Austin.

Jackson, Michael A.

1998 The Nature of Fire-Cracked Rock: New Insights from Ethnoarchaeological and Laboratory Experiments. Unpublished Master's thesis, Department of Anthropology, Texas A\&M University, College Station.

Johnson, LeRoy, Jr.

1994 The Life and Times of Toyah-Culture Folk as Seen from the Buckhollow Encampment, Site 41KM16 of Kimble County, Texas. Office of the State Archeologist Report 38. Texas Historical Commission, Austin.

Kelley, J. Charles, and Thomas N. Campbell

1942 What Are the Burnt Rock Mounds of Texas? American Antiquity 7:319-322.

Kludt, Trevor J.

2006 Batch Processing and Bulk Acquisition of Agave in the Desert Southwest. Ph.D. dissertation, Department of Anthropology, University of New Mexico, Albuquerque. University Microfilms, Ann Arbor.

Kramer, Stephanie

2000 Camas Bulbs, the Kalapuya, and Gender: Exploring Evidence of Plant Food Intensification in the Willamette Valley of Oregon. Unpublished Master's thesis, Department of Anthropology, University of Oregon, Eugene.

Leach, Jeff D., and C. Britt Bousman

2001 Cultural and Secondary Formation Processes: On the Dynamic Accumulation of Burned Rock Middens. In Test Excavations at the Culebra Creek Site, 41BX126, Bexar County, Texas, by David L. Nickels, C. Britt Bousman, Jeff D. Leach, and Diane A. Cargill, pp. 119-145. Archaeological Survey Report 265. Center for Archaeological Research, University of Texas at San Antonio.

Leach, Jeff D., C. Britt Bousman, and David L. Nickels 2005 Assigning Context to Artifacts in Burned-Rock Middens. Journal of Field Archaeology 30:201-203.

Leach, Jeff D., Glenn R. Gibson, and Jan Van Loo

2006 Human Evolution, Nutritional Ecology and Prebiotics in Ancient Diet. Bioscience and Microflora 25:1-8.

Lepofsky, Dana, and Ken Lertzman

2008 Documenting Ancient Plant Management in the Northwest of North America. Botany 86:129-145.

Lepofsky, Dana, and Sandra Peacock

2004 A Question of Intensity: Exploring the Role of Plant Foods in Northern Plateau Prehistory. In Complex HunterGatherers: Evolution and Organization of Prehistoric Communities on the Plateau of Northwestern North America, edited by William C. Prentiss and Ian Kuijt, pp. 3648. University of Utah Press, Salt Lake City.

Lepofsky, Dana, David M. Schaepe, Anthony P. Graesch, Michael Lenert, Patricia Ormerod, Keith Thor Carlson, Jeanne E. Arnold, Michael Blake, Patrick Moore, and John J. Clague
2009 Exploring Stó:Lō-Coast Salish Interaction and Identity in Ancient Houses and Settlements in the Fraser Valley, British Columbia. American Antiquity 74:595-626.

Lewis, R. Barry

1988 Fires on the Bayou: Cultural Adaptations in the Mississippi Sound Region. Southeastern Archaeology 7:109_ 123.

Luke, Clive J.

1983 The Musk Hog Canyon Project, Crockett County, Texas. Publications in Archaeology Report 24. Texas State Department of Highways and Transportation, Highway Design Division.

Mauldin, Raymond P., David L. Nickels, and Cory J. Broehm 2003 Archaeological Testing to Determine the National Register Eligibility Status of 18 Prehistoric Sites on Camp Bowie, Brown County, Texas. Archaeological Survey Report 334. Center for Archaeological Research, University of Texas at San Antonio.

Mehalchick, Gemma, Douglas R. Boyd, Karl W. Kibler, and Christopher W. Ringstaff

2004 Shifting Sands and Geophytes: Geoarchaeological Investigations at Paluxy Sites on Fort Hood, Texas. Research Report 48. Archaeological Resource Management Series, United States Army Fort Hood, Texas.

Mentzer, Susan M.

2012 Microarchaeological Approaches to the Identification and Interpretation of Combustion Features in Prehistoric Archaeological Sites. Journal of Archaeological Method and Theory, DOI:10.1007/s10816-012-9163-2.

Milburn, Douglas M., U. K. Doan, and Joanna Huckabee

2009 Spatial and Temporal Distributions of Archaeological Heated-Rock Cooking Structures in the Transverse Mountain Range: Proposed Markers of Land-Use Shifts since the Early Holocene. Proceedings of the Society of California Archaeology 22:1-21.

Miller, Myles R., Tim B. Graves, Moira Ernst, and Michael Stowe

2011 Burned Rock Middens of the Southern Sacramento Mountains. Cultural Resource Report 09-28. Environmental Division, Directorate of Public Works, Fort Bliss Garrison Command, El Paso.

Movius, Hallam L., Jr.

1966 The Hearths of the Upper Perigordian and Aurignacian Horizons at the Abri Pataud, Les Eyzies (Dordogne) and Their Possible Significance. American Anthropologist 68:296-325.

Nelson, Kit

2010 Environment, Cooking Strategies and Containers. Journal of Anthropological Archaeology 29:238-247.

Petraglia, Michael D.

2002 The Heated and the Broken: Thermally Altered Stone, Human Behavior, and Archaeological Site Formation. North American Archaeologist 23:241-269.

Pollack, David (editor)

2008 The Archaeology of Kentucky: An Update, Vol. 1. State Historic Preservation Comprehensive Plan Report No. 3. Kentucky Heritage Council, Frankfort.

Rehder, J. E.

2000 The Mastery and Uses of Fire in Antiquity. McGillQueen's University Press, Montreal.

Ricklis, Robert A., and Michael B. Collins

1994 Archaic and Late Prehistoric Human Ecology in the Middle Onion Creek Valley, Hays County, Texas. Studies in Archeology 19. Texas Archeological Research Laboratory, University of Texas at Austin.

Schalk, Randall, and Daniel Meatte

1993 The Archaeological Features. In The Archaeology of 
Chester Morse Lake: Long-Term Human Utilization of the Foothills in the Washington Cascade Range, edited by Stephen R. Samules, pp. 10.3-10.42. Center for Northwest Anthropology, Washington State University, Pullman.

Schlanger, Sarah H.

1992 Recognizing Persistent Places in Anasazi Settlement Systems. In Space, Time and Archaeological Landscapes, edited by Jaqueline Rossignol and LuAnn Wandsnider, pp. 91-112. Plenum Press, New York.

Siegel, Robert, and John R. Howell

2001 Thermal Radiation Heat Transfer. 4th ed. Taylor and Francis, New York.

Smith, Craig S., and William Martin

2001 Sego Lilies and Prehistoric Foragers: Return Rates, Pit Ovens and Carbohydrates. Journal of Archaeological Science 28:169-183.

Stark, Richard T.

1997 Piedras Calientes: Ethnohistory, Experimental Archaeology, and Cooking with Hot Stones. Unpublished Master's thesis, Department of Anthropology, University of Texas at Austin.

2002 Comidas de la Tierra: An Ethnoarcheology of Earth Ovens. Ph.D. dissertation, Department of Anthropology, University of Texas at Austin.

Straus, Lawrence G.

2006 Of Stones and Bones: Interpreting Site Function in the Upper Paleolithic and Mesolithic of Western Europe. Journal of Anthropological Archaeology 25:500-509.

Sullivan, Alan P., III, Robert A. Cook, Matthew P. Purtill, and Patrick M. Uphus

2001 Economic and Land-Use Implications of Prehistoric Fire-Cracked-Rock Piles in Northern Arizona. Journal of Field Archaeology 28:367-382.

Thoms, Alston V.

1989 The Northern Roots of Hunter-Gatherer Intensification: Camas and the Pacific Northwest. Ph.D. dissertation, Washington State University, Pullman. University Microfilms, Ann Arbor.

2003 Cook-Stone Technology in North America: Evolutionary Changes in Domestic Fire Structures during the Holocene. In Le Feu Domestique et ses Structures au Neolithique et aux Ages des Metaux, edited by MarieChantal Frère-Sautot and Christophe Bontemps, pp. 8796. Collections Prehistoires. Editions Monique Mergoil, Saint-Apollinaire, France.

2008a Ancient Savannah Roots of the Carbohydrate Revolution in South-Central North America. Plains Anthropologist 53:121-136.

2008b The Fire Stones Carry: Ethnographic Records and Archaeological Expectations for Hot-Rock Cookery in Western North America. Journal of Anthropological Archaeology 27:443-460.

2009 Rocks of Ages: Propagation of Hot-Rock Cookery in Western North America. Journal of Archaeological Science 36:573-591.

Thoms, Alston V., John L. Montgomery, and Alice W. Portnoy 1981 An Archaeological Survey of a Portion of the Choke Canyon Reservoir Area in McMullen and Live Oak Counties, Texas. Choke Canyon Series 3. Center for Archaeological Research, University of Texas at San Antonio.

Torrence, Robin, Vince Neal, Trudy Doelman, Ed Rhodes, Chris McKee, Hugh Davies, Roberto Bonetti, Alessandra Gugliemetti, Alberty Manzoni, Massimo Oddone, Jeff Parr, and Cleland Wallace

2004 Pleistocene Colonization of the Bismarck Archipelago: New Evidence from West New Britain. Archaeology in Oceania 39:101-130.
Waechter, Sharon A.

2005 Late-Period Resource Intensification in Sierra Valley, Eastern Plumas County: A Response to the Medieval Climatic Anomaly. Proceedings of the Society of California Archaeology 18:45-52.

Wandsnider, LuAnn

1997 The Roasted and the Boiled: Food Composition and Heat Treatment with Special Emphasis on Pit-Hearth Cooking. Journal of Anthropological Archaeology 16:148.

1999 Late Prehistoric High Plains Foragers: Starving Nomads or Affluent Foragers? Great Plains Research: A Journal of Natural and Social Science 9:9-39.

Wandsnider, LuAnn, and Y. S. Chung

2003 Islands of Geophytes: Sego Lily Patch Density in a High Plains Habitat. In Islands on the Plains: Ecological, Social, and Ritual Use of Landscapes, edited by Marcel Kornfeld and Alan J. Osborn, pp. 220-242. University of Utah Press, Salt Lake City.

Whalen, Michael E., and Paul E. Minnis

2009 The Neighbors of Casas Grandes: Medio Period Communities of Northwestern Chihuahua. University of Arizona Press, Tucson.

Wilson, Ernest W.

1930 Burned Rock Mounds of South-West Texas. Bulletin of the Texas Archeological and Paleontological Society 2:59-63.

Wrangham, Richard

2009 Catching Fire: How Cooking Made Us Human. Basic Books, New York.

Yu, Pei-Lin

2009 Ancient Pit Cooking in the American Southwest and Pacific Northwest: A Study in Foraging Intensification. VDM Verlag, Saarbrücken.

\section{Notes}

1. The research implications of cooking technology in general and earth oven cookery in particular are noted in this article but are not discussed in detail, as is the case with our ideas about land-use intensification, including the kinds of foods baked in earth ovens. In light of word limitations and some of the reviewers' requests for more details, we necessarily refer readers to the articles cited herein for such information.

2. We consider the modifiers fire-cracked, burned, heated, fire-altered, thermally altered, heat-fractured, once-hot, and so forth to be synonyms. We usually prefer fire-cracked or burned simply because these are evocative and widely used. All rocks that come in sustained contact with fire suffer thermal stress and begin to fracture, although the fractures may not be externally visible (e.g., Jackson 1998; Schalk and Meatte 1993).

3. The current nomenclature and technological opacity are readily apparent. American Antiquity articles over the past two decades alone have employed many different termshearth, earth oven, hearth oven, rock oven, hearth pit, pit feature, pit oven, roasting pit, slab-lined cylindrical basin, rockenclosed feature, and fire-cracked rock piles, among others-to designate the cooking facilities that we call earth ovens. Over the past 50 years archaeological projects across the North American continent have encountered tens of thousands of similar cooking features, resulting in a multitude of published cooking feature nomenclatures and discussions. This bewil- 
dering array of terminology, description, and functional interpretation - or lack thereof-demonstrates that the underlying technology for this basic component of hunter-gatherer subsistence is not well understood.

4. We use the term pit in a broad sense, meaning a humanmade hole in the ground, and note that, characteristically, aboriginal cooking features were placed in relatively shallow, basin-shaped pits far more often than deep, steep-sided pits.

5 . Some rocks tend to disintegrate explosively when heated due to the presence of water trapped within internal fractures or voids or perhaps relatively high silica content. Experienced earth oven cooks know how to recognize and avoid such rocks.

6. Among the relatively common variations on the earth oven theme are lining the basin pit with tabular rocks, adding a second or upper layer of hot rocks, placing the rocks above the food, and building a second fire atop the earthen cap.

7. Earth oven cookery and BRMs in the study area are illustrated and described in several online exhibits including http://www.texasbeyondhistory.net/plateaus/, http://www.texas beyondhistory.net/honey/, and http://www.texasbeyondhistory .net/bowie/.
8. Thermally altered rocks are also generated by other cook-stone technologies, such as stone boiling, but the amount of spent rocks generated by earth ovens is usually far greater (Nelson 2010; Thoms 2008b, 2009).

9. In our experiences in the study area and the Pacific Northwest, fresh oven rocks are rarely larger than about 30$40 \mathrm{~cm}$ because they would simply be too unwieldy to maneuver except in the case of relatively thin slabs, such as those used to line oven pits.

10. Diagnostic residues and microfossils may be present within the archaeological remains of earth ovens and are the subject of several lines of ongoing research. But they, too, are subject to palimpsest "contamination" factors that are not easy to rule out.

Submitted March 13, 2013; Revised June 7, 2013; Accepted October 2, 2013. 